\title{
Defining a Path Toward the Use of Fast-Scan Cyclic Voltammetry in Human Studies
}

\author{
Suelen Lucio Boschen ${ }^{1 *}$, James Trevathan ${ }^{2}$, Seth A. Hara ${ }^{3}$, Anders Asp ${ }^{1,4}$ and \\ J. Luis Lujan ${ }^{1,5}$
}

${ }^{1}$ Applied Computational Neurophysiology and Neuromodulation Laboratory, Department of Neurologic Surgery, Mayo Clinic, Rochester, MN, United States, ${ }^{2}$ Department of Biomedical Engineering, University of Wisconsin-Madison, Madison, WI, United States, ${ }^{3}$ Division of Engineering, Mayo Clinic, Rochester, MN, United States, ${ }^{4}$ Mayo Clinic Graduate School of Biomedical Sciences, Mayo Clinic, Rochester, MN, United States, ${ }^{5}$ Department of Physiology and Biomedical Engineering, Mayo Clinic, Rochester, MN, United States

\section{OPEN ACCESS}

Edited by:

Grzegorz Marcin Wójcik, Marie Curie-Sklodowska University,

Poland

Reviewed by:

Jit Muthuswamy,

Arizona State University, United States

Vassiliy Tsytsarev,

University of Maryland, College Park,

United States

Parastoo Hashemi,

University of South Carolina,

United States

${ }^{*}$ Correspondence:

Suelen Lucio Boschen

Souza.suelen@mayo.edu

Specialty section:

This article was submitted to

Neural Technology,

a section of the journal

Frontiers in Neuroscience

Received: 20 June 2021

Accepted: 25 October 2021

Published: 12 November 2021

Citation:

Lucio Boschen S, Trevathan J,

Hara SA, Asp A and Lujan JL (2021)

Defining a Path Toward the Use

of Fast-Scan Cyclic Voltammetry

in Human Studies.

Front. Neurosci. 15:728092.

doi: 10.3389/fnins.2021.728092
Fast Scan Cyclic Voltammetry (FSCV) has been used for decades as a neurochemical tool for in vivo detection of phasic changes in electroactive neurotransmitters in animal models. Recently, multiple research groups have initiated human neurochemical studies using FSCV or demonstrated interest in bringing FSCV into clinical use. However, there remain technical challenges that limit clinical implementation of FSCV by creating barriers to appropriate scientific rigor and patient safety. In order to progress with clinical FSCV, these limitations must be first addressed through (1) appropriate pre-clinical studies to ensure accurate measurement of neurotransmitters and (2) the application of a risk management framework to assess patient safety. The intent of this work is to bring awareness of the current issues associated with FSCV to the scientific, engineering, and clinical communities and encourage them to seek solutions or alternatives that ensure data accuracy, rigor and reproducibility, and patient safety.

Keywords: clinical neurochemistry, deep brain stimulation, fast scan cyclic voltammetry, intraoperative, neurochemical signaling, neurophysiology

\section{INTRODUCTION}

Fast scan cyclic voltammetry (FSCV) is an electrochemistry technique used for over 30 years to study rapid neurotransmission in the brain of anesthetized and awake and behaving animals (Ganesana et al., 2017; Rodeberg et al., 2017). FSCV detects electroactive neurotransmitters by varying the electric potential between a small working electrode (on the order of a few micrometers in diameter) and a larger reference electrode (on the order of millimeters in diameter). This process oxidizes and/or reduces neurotransmitters at specific potentials and results in electrical currents with amplitude proportional to the concentration of the neurotransmitter in the extracellular space (Clark et al., 2010; Bucher and Wightman, 2015; Figure 1). Under the right conditions, this enables the estimation of changes in neurotransmitter levels with high spatial and temporal resolution, sensitivity, and chemical selectivity (Borland and Michael, 2007; Johnson et al., 2017).

However, in vivo neurotransmitter measurement via FSCV can be confounded by several factors including interferant molecules with similar oxidation/reduction potentials to the neurotransmitter of interest, electrode biofouling, shifts in $\mathrm{pH}$ and ionic concentrations, or increased oxygenated blood flow in the electrode microenvironment. Additionally, electrical and motion artifacts 
can disrupt the electrochemical interface creating artificial signals that appear similar to neurotransmitter release (Ariansen et al., 2012; Lee et al., 2017). In small animal studies, a set of guidelines known as the "Five Golden Rules" is typically used to validate and increase reliability of in vivo neurotransmitter measurements (Clark et al., 2010). These Golden Rules include (i) identification of neurotransmitter-specific electrochemical signatures, (ii) additional confirmation of the chemical identity of each recorded neurotransmitter (e.g., through microdialysis at the FSCV site), (iii) anatomical validation of the recording location, (iv) kinetic validation of spontaneous or evoked changes in neurotransmitter concentration, and (v) pharmacological validation of recorded neurotransmitters (Clark et al., 2010; Meunier et al., 2018). These guidelines are instrumental toward ensuring the validity of pre-clinical FSCV measurements.

In the last 10 years, there has been a trend toward the use of FSCV in patients undergoing neurosurgical procedures to study human neurophysiology (Bucher and Wightman, 2015). Undoubtedly, advancing the knowledge of underlying mechanisms and biological processes associated with the complex chemistry of the human brain is critical to the development of new and improved therapeutic interventions. For example, the clinical use of FSCV may allow characterization of changes in neurochemical signaling evoked by deep brain stimulation (DBS) and could potentially advance treatment of neurologic diseases (Lee et al., 2017). However, clinical questions that can be currently answered with FSCV are limited by technical barriers that must be addressed to ensure that clinical studies have appropriate scientific rigor and mitigate risks to patient safety. To address potential confounds during data acquisition in humans, extensive pre-clinical testing of new technologies designed to enable human use must be performed. Additionally, there is a critical need for appropriate pre-clinical studies mimicking the clinical environment. Risks should be weighed against actual benefits of the clinical work to ensure patient safety and high-quality data. The objective of this manuscript is to initiate a discussion between the scientific, engineering, and clinical communities regarding these issues and encourage collaborative solutions that are safe and suitable for neurochemical measurements in clinical studies.

\section{INVESTIGATIONAL USE OF FAST SCAN CYCLIC VOLTAMMETRY}

While a clinical study may not directly benefit the patients participating in the study, studies are likely to improve future patient care. Notably, treatment improvements and benefits to patients can only be accomplished by leveraging appropriate pre-clinical studies and scientific rigor.

\section{Large Animal Studies}

Anatomical and physiological similarities, as well as behavioral correlates to human conditions often make non-human primate and swine models a better alternative for translational research (Lind et al., 2007; Phillips et al., 2014). Unfortunately, only a small number of FSCV studies have investigated neurotransmitter release in vivo using large animal models (Table $\mathbf{1}$ ).

Dopamine release in large animals was first measured via FSCV in 1984 in a non-human primate model (CheneyThamm et al., 1984). In the study, the investigators detected increased current peaks in the oxidation range for dopamine in the caudate in response to pleasant stimuli and amphetamine administration. However, these measurements were not properly validated accordingly to the Five Golden Rules, i.e., use of rudimentary electrochemical parameters and working electrode material, which reduces reliability on the data collected.

It was not until 10 years later that FSCV was used again in non-human primates to demonstrate reduced dopaminergic release in response to electrical stimulation of the medial forebrain bundle in an anesthetized 1-methyl-4-phenyl-1,2,3,6tetrahydropyridine marmoset model of Parkinson's Disease (Earl et al., 1998). In this study, investigators validated dopamine measurements by confirming dopamine-specific electrochemical signature, and by demonstrating anatomically, electrically, and pharmacologically evoked changes in the kinetics of dopamine concentration.

Since then, other studies using FSCV in swine and nonhuman primate models have utilized FSCV recording electrodes (including both working and reference electrodes), recording systems, and analysis techniques that had been well validated in small animal models (Adams, 1976; Stamford et al., 1984; Millar et al., 1985; Suaud-Chagny et al., 1992), ensuring rigor and data reproducibility. Consistently, they have reported increased dopamine release in the caudate-putamen as a function of reward (Yoshimi et al., 2015), and electrical stimulation of the subthalamic nucleus (Nakajima et al., 2017), fornix, and ventral tegmental area (Lee et al., 2017). In addition, FSCV has been used to detect cortical adenosine during seizure termination in swine (Van Gompel et al., 2014), and to serve as the basis of a neurochemical-based closed-loop DBS system in rodent, swine, and non-human primate (Ariansen et al., 2012). More recently, studies in non-human primates proposed new strategies to overcome challenges regarding chronic FSCV recordings in large animals, such as target optimization and spatial resolution (Schluter et al., 2014; Schwerdt et al., 2017b). However, they could not resolve other limitations such as tissue damage, glial encapsulation, electrode biofouling, and material deterioration that caused continuous signal loss (Kozai et al., 2015).

Overall, these pre-clinical studies show the feasibility of recording of neurotransmitters via FSCV in acute and longterm animal models. However, they do not directly address the significant barriers to clinical use of FSCV, especially in the operating room setting.

\section{Scientific Rigor}

It is not possible to apply the Five Golden Rules for neurotransmitter measurement in the human operating room. However, many of the potential confounds for FSCV measurement in clinical studies can be anticipated. Data analysis, including calibration and signal extraction algorithms designed to distinguish neurochemical signals from interferents and noise, depend mainly on the electrochemical properties of the 

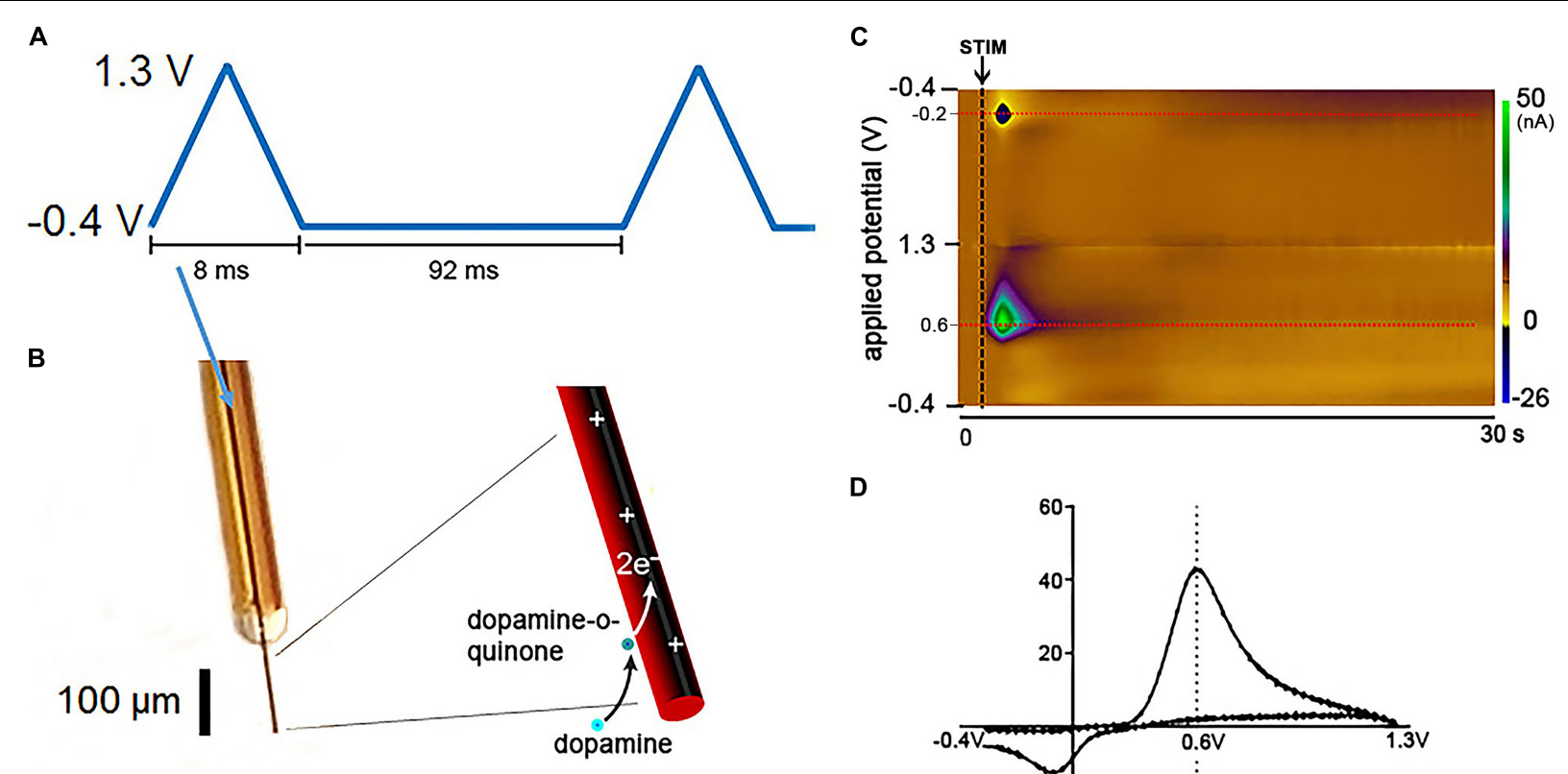

D

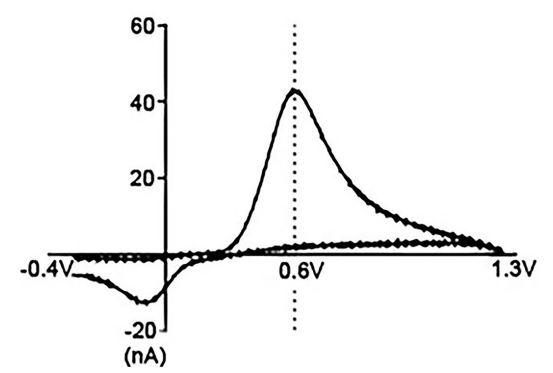

FIGURE 1 | Fast Scan Cyclic Voltammetry in dopamine detection. Schematic of FSCV dopamine detection at CFM. (A) Triangular waveform typically used for catecholamine detection. Each waveform ranging from -0.4 to $1.3 \mathrm{~V}$ takes $8.0 \mathrm{~ms}$ to be delivered and is followed by $92 \mathrm{~ms}$ of a constant potential held at $-0.4 \mathrm{~V}$. Therefore, each waveform cycle takes $100 \mathrm{~ms}$ to be completed. (B) Illustration of a silica tubing-insulated CFM with the oxidation/reduction reactions of dopamine at the carbon fiber exposed tip. (C) Pseudocolor-plot shows the changes in oxidation ( $0.6 \mathrm{~V})$ and reduction $(-0.2 \mathrm{~V})$ currents (red dashed lines) corresponding to dopamine release evoked by medial forebrain bundle electrical stimulation (black arrow and dashed line) in an anesthetized rat. The oxidation and reduction currents (in $\mathrm{nA}$ ) are represented in the color scale on the right side of the pseudocolor-plot. The pseudocolor-plot shows 300 triangular waveform cycles (-0.4, 1.3, and $-0.4 \mathrm{~V}$ ) applied from 0 to $30 \mathrm{~s}$ at $10 \mathrm{~Hz}$. Additional time after neurotransmitter release is typically showed in pseudocolor-plots to demonstrate that the background current returns to baseline levels. (D) Dopamine voltammogram associated with the oxidation and reduction currents represented in the pseudocolor-plot. Adapted with permission from The Schwerdt lab (http://schwerdt.pitt.edu/resources.html).

FSCV recording system. For example, the material composition, configuration, and surface properties of FSCV electrodes define the electrochemical properties of the recording system and can affect the recorded signals (Bucher and Wightman, 2015; Ganesana et al., 2017; Johnson et al., 2017; Meunier et al., 2018; Puthongkham and Venton, 2019). Additionally, electrode materials and recording system commonly used in small animal models must be modified to ensure biocompatibility and the ability to reach deep brain targets. Furthermore, confirmation of measured signals accuracy via pharmacologic validation or alternate neurochemical technique in humans is largely not possible in the operating room due to increased hemorrhage risk with additional alternate neurochemical recordings (Sansur et al., 2007; Park et al., 2011), and risk of pharmacological manipulations interfering with patient's wellbeing during the procedure. Moreover, the time required for recording system stabilization and signal detection is large, but the total allowed operating room time for safe experimental procedures is limited. For example, in acute animal experiments using a single Carbon fiber microelectrode (CFM), identifying an optimal area for recording evoked neurochemical release within a given target region can take several minutes to a few hours. This process requires slowly moving the electrode to different locations within the target and allowing enough time for the signal drift to settle after each movement. In contrast, Institutional Review
Boards (IRBs) typically require that the research use of FSCV adds no longer than 15-60 min to the overall procedure, which varies across institutions with an average duration of $4 \mathrm{~h}$. The compressed timeframe of the operating room environment combined with patient safety concerns require the use of one single track, with very little or no time available for electrode repositioning for recording optimization. The operating room environment is also full of sources of noise and interference from electronic equipment that can affect FSCV recordings in unexpected ways. Although not exhaustive, the next sections highlight the need for appropriate pre-clinical studies addressing changes to the recording methods, experimental paradigm, and data analysis techniques beyond what is described in the FSCV literature before human neurophysiology studies can be performed.

\section{Novel Working Electrodes Designs}

The working electrode is typically composed of carbon-based materials (Table 2) to improve biocompatibility and chemical inertness, as well as to reduce background currents that interfere with the detection of neurochemical signatures associated with specific neurotransmitters (McDermott and McCreery, 1994; Patel et al., 2013; Rodeberg et al., 2017; Roberts and Sombers, 2018). CFMs have become the standard working electrode for pre-clinical FSCV recordings. The popularity of CFMs can 
TABLE 1 | Fast scan cyclic voltammetry studies in large animals.

\begin{tabular}{|c|c|c|c|c|c|}
\hline Study & $\begin{array}{l}\text { Species (common } \\
\text { name), } n\end{array}$ & Goal & FSCV parameters & FSCV electrodes & Major findings \\
\hline $\begin{array}{l}\text { Cheney- } \\
\text { Thamm et al., } \\
1984\end{array}$ & $\begin{array}{l}\text { Macaca nemestrina } \\
\text { (Pigtail macaque) } \\
2 \text { females, } \\
2 \text { males }\end{array}$ & $\begin{array}{l}1 \text { - Determine if } \\
\text { D-amphetamine increased } \\
\text { current oxidation in the } \\
\text { caudate of macaques, as } \\
\text { previously reported in } \\
\text { rodents. } \\
2 \text { - Determine if altered } \\
\text { behavioral states induced } \\
\text { by D-amphetamine affected } \\
\text { oxidation peaks. }\end{array}$ & $\begin{array}{l}\text { Triangular waveform from } \\
-0.2 \text { to }+0.6 \mathrm{~V} \text { at } 10 \mathrm{mV} / \mathrm{s}\end{array}$ & $\begin{array}{l}\text { Working electrode: Teflon coated } \\
250 \mu \mathrm{m} \text { diameter SS wire } \sim 1 \mathrm{~mm} \\
\text { exposed tip Reference electrode: } \\
\mathrm{Ag} / \mathrm{AgCl} \text { wires }\end{array}$ & $\begin{array}{l}\text { D-Amphetamine treatment } \\
\text { enhances dopaminergic } \\
\text { signaling during presentation of } \\
\text { both pleasant and unpleasant } \\
\text { stimuli. }\end{array}$ \\
\hline $\begin{array}{l}\text { Cheney- } \\
\text { Thamm et al., } \\
1987\end{array}$ & $\begin{array}{l}\text { Macaca nemestrina } \\
\text { (Pigtail macaque) } \\
2 \text { females, } \\
1 \text { male }\end{array}$ & $\begin{array}{l}\text { Demonstrate the feasibility } \\
\text { of using acetaminophen as } \\
\text { in vivo internal standard for } \\
\text { electrode calibration. }\end{array}$ & $\begin{array}{l}\text { Triangular waveform from } \\
-0.2 \text { to }+0.6 \mathrm{~V} \text { at } 10 \mathrm{mV} / \mathrm{s}\end{array}$ & $\begin{array}{l}\text { Working electrode: Teflon coated } \\
250 \mu \mathrm{m} \text { diameter SS wire } \\
\text { Reference electrode: } \mathrm{Ag} / \mathrm{AgCl} \text { wire }\end{array}$ & $\begin{array}{l}\text { Acetaminophen peak signal } \\
\text { was successfully detected by } \\
\text { FSCV in the non-human } \\
\text { primate brain. }\end{array}$ \\
\hline Earl et al., 1998 & $\begin{array}{l}\text { Callithrix jacchus } \\
\text { (marmoset) } \\
8 \text { (unspecified } \\
\text { number of males } \\
\text { and females) }\end{array}$ & $\begin{array}{l}\text { Evaluate electrically-evoked } \\
\text { dopaminergic efflux in the } \\
\text { striatum of normal and } \\
\text { MPTP-treated marmosets. }\end{array}$ & $\begin{array}{l}\text { Triphasic triangular } \\
\text { waveform from }-1.0 \text { to } \\
+1.4 \mathrm{~V} \text { and resting } \\
\text { potential at } 0 \mathrm{~V} \text { at } 480 \mathrm{~V} / \mathrm{s} \\
\text { at } 2 \mathrm{~Hz}(15 \mathrm{~ms} / \mathrm{scan})\end{array}$ & $\begin{array}{l}\text { Working electrode: Glass insulated } \\
7 \mu \mathrm{m} \text { diameter } \mathrm{CFM} \sim 20-50 \mu \mathrm{m} \\
\text { exposed tip } \\
\text { Reference electrode: } \mathrm{Ag} / \mathrm{AgCl} \text { wire }\end{array}$ & $\begin{array}{l}\text { Dopamine signaling in the } \\
\text { striatum remains responsive to } \\
\text { MFB electrical stimulation after } \\
\text { dopaminergic lesion induced by } \\
\text { MPTP. }\end{array}$ \\
\hline $\begin{array}{l}\text { Shon et al., } \\
2010\end{array}$ & $\begin{array}{l}\text { Sus scrofa } \\
\text { domesticus (Swine) } \\
4 \text { males }\end{array}$ & $\begin{array}{l}1 \text { - Investigate if electrical } \\
\text { stimulation of the STN } \\
\text { evokes striatal dopamine } \\
\text { release in a large animal } \\
\text { model. } \\
2 \text { - Demonstrate feasibility } \\
\text { of performing FSCV } \\
\text { recordings in an } \\
\text { environment similar to } \\
\text { human OR. }\end{array}$ & $\begin{array}{l}\text { Triangular waveform from } \\
-0.4 \text { to }+1.5 \mathrm{~V} \text { at } 400 \mathrm{~V} / \mathrm{s} \\
\text { at } 10 \mathrm{~Hz}\end{array}$ & $\begin{array}{l}\text { Working electrode: glass insulated } \\
\text { CFM (characteristics unspecified) } \\
\text { Reference electrode: } \mathrm{Ag} / \mathrm{AgCl} \text { wire }\end{array}$ & $\begin{array}{l}\text { STN electrical stimulation } \\
\text { evoked intensity and frequency } \\
\text { dependent striatal dopamine } \\
\text { release. }\end{array}$ \\
\hline Lee et al., 2011 & $\begin{array}{l}\text { Sus scrofa } \\
\text { domesticus (Swine) } \\
\text { Unknown number } \\
\text { of animals - males }\end{array}$ & $\begin{array}{l}\text { Use a wireless } \\
\text { instantaneous } \\
\text { neurotransmitter } \\
\text { concentration } \\
\text { measurement system to } \\
\text { monitor electrochemical } \\
\text { signaling in the brain. }\end{array}$ & $\begin{array}{l}\text { Triangular waveform from } \\
-0.4 \text { to }+1.5 \mathrm{~V} \text { at } 400 \mathrm{~V} / \mathrm{s} \\
\text { at } 10 \mathrm{~Hz}\end{array}$ & $\begin{array}{l}\text { Working electrode: CFM } \\
\text { (characteristics unspecified) } \\
\text { Reference electrode: } \mathrm{Ag} / \mathrm{AgCl} \text { wire }\end{array}$ & $\begin{array}{l}\text { Dopamine signaling responded } \\
\text { in sigmoidal-like fashion to } \\
\text { pulse intensity and pulse-width } \\
\text { STN electrical stimulation. }\end{array}$ \\
\hline $\begin{array}{l}\text { Ariansen et al., } \\
2012\end{array}$ & $\begin{array}{l}\text { Macaca mulatta } \\
\text { (Rhesus macaque) } \\
3 \text { (unspecified } \\
\text { number of males } \\
\text { and females) }\end{array}$ & $\begin{array}{l}\text { Determine if changes in } \mathrm{pH} \\
\text { and oxygen are associated } \\
\text { with reward and/or reward } \\
\text { prediction. }\end{array}$ & $\begin{array}{l}\text { Dopamine }- \text { Triangular } \\
\text { waveform from }-0.4 \text { or } \\
-0.6 \mathrm{~V} \text { to }+1.0 \mathrm{or}+1.4 \mathrm{~V} \text { at } \\
400 \mathrm{~V} / \mathrm{s} \text { at } 10 \mathrm{~Hz} \text {. } \\
\text { Oxygen - from } 0.0 \text { to } \\
+0.8 \mathrm{~V} \text {, a reversal to }-1.4 \mathrm{~V} \text {, } \\
\text { and then returned to } 0.0 \mathrm{~V} \text {, } \\
\text { at } 10 \mathrm{~Hz} \text {. }\end{array}$ & $\begin{array}{l}\text { Working electrode: glass insulated } \\
12 \mu \mathrm{m} \text { diameter CFM with } 250 \mu \mathrm{m} \\
\text { exposed tip and coated with Nafion } \\
\text { and 4-sulfobenzene; } 33 \mu \mathrm{m} \text { coated } \\
\text { with Nafion. } \\
\text { Reference electrode: } \mathrm{Ag} / \mathrm{AgCl} \text { wire }\end{array}$ & $\begin{array}{l}\text { Oxygen and } \mathrm{pH} \text { changes were } \\
\text { associated with the reward and } \\
\text { cues that predicted reward. } \\
\text { Dopamine responses evoked } \\
\text { by reward and cues were } \\
\text { overshadowed by pH changes } \\
\text { detected by FSCV. }\end{array}$ \\
\hline $\begin{array}{l}\text { Schluter et al., } \\
2014\end{array}$ & $\begin{array}{l}\text { Macaca mulatta } \\
\text { (Rhesus macaque) } \\
2 \text { males }\end{array}$ & $\begin{array}{l}\text { Demonstrate the feasibility } \\
\text { of using FSCV to measure } \\
\text { real-time changes of } \\
\text { dopamine levels in the } \\
\text { striatum of macaques. }\end{array}$ & $\begin{array}{l}\text { Triangular waveform from } \\
-0.4 \text { to }+1.3 \mathrm{~V} \text { at } 400 \mathrm{~V} / \mathrm{s} \\
\text { at } 10 \mathrm{~Hz}\end{array}$ & $\begin{array}{l}\text { Working electrode: fused silica } \\
\text { capillary CFM - 125-150 } \mu \mathrm{m} \\
\text { exposed tip and } 7 \mu \mathrm{m} \text { diameter. } \\
\text { Reference electrode: } \mathrm{Ag} / \mathrm{AgCl} \text { wire }\end{array}$ & $\begin{array}{l}\text { Demonstrated striatal } \\
\text { dopamine responses evoked } \\
\text { by VTA/SNc and striatum } \\
\text { electrical stimulation, and by } \\
\text { unexpected rewards in awake } \\
\text { monkeys. }\end{array}$ \\
\hline $\begin{array}{l}\text { Van Gompel } \\
\text { et al., } 2014\end{array}$ & $\begin{array}{l}\text { Sus scrofa } \\
\text { domesticus (Swine) } \\
3 \text { males }\end{array}$ & $\begin{array}{l}\text { Determine if extracellular } \\
\text { adenosine concentration } \\
\text { increases during seizure } \\
\text { termination (in swine and } \\
\text { humans).* }\end{array}$ & $\begin{array}{l}\text { Triangular waveform from } \\
-0.4 \text { to }+1.5 \mathrm{~V} \text { at } 900 \mathrm{~V} / \mathrm{s} \\
\text { at } 10 \mathrm{~Hz}\end{array}$ & $\begin{array}{l}\text { Working electrode: } \mathrm{CFM}-100 \mu \mathrm{m} \\
\text { exposed tip and } 7 \mu \mathrm{m} \text { diameter } \\
\text { Reference electrode: } \mathrm{Ag} / \mathrm{AgCl} \text { wire }\end{array}$ & $\begin{array}{l}\text { Increased adenosine levels } \\
\text { were observed just prior to } \\
\text { seizure termination. FSCV } \\
\text { recordings were also performed } \\
\text { in human patients.* }\end{array}$ \\
\hline $\begin{array}{l}\text { Yoshimi et al., } \\
2015\end{array}$ & $\begin{array}{l}\text { Macaca fuscata } \\
\text { (Japanese } \\
\text { macaques) } \\
3 \text { females }\end{array}$ & $\begin{array}{l}\text { Measure changes in } \\
\text { dopamine levels associated } \\
\text { with reward response. }\end{array}$ & $\begin{array}{l}\text { Triangular waveform from } \\
-0.4 \text { to }+1.3 \mathrm{~V} \text { at } 400 \mathrm{~V} / \mathrm{s} \\
\text { at } 10 \mathrm{~Hz}\end{array}$ & $\begin{array}{l}\text { Working electrode: fused silica CFM } \\
\text { and glass capillary CFM - } 7 \mu \mathrm{m} \\
\text { diameter and } 300 \mu \mathrm{m} \text { exposed tip. } \\
\text { Reference electrode: } \mathrm{Ag} / \mathrm{AgCl} \text { wire }\end{array}$ & $\begin{array}{l}\text { Dopamine release induced by } \\
\text { electrical stimulation and } \\
\text { reward signals was detected in } \\
\text { the macaque striatum by FSCV } \\
\text { on carbon fibers. }\end{array}$ \\
\hline Min et al., 2016 & $\begin{array}{l}\text { Macaca mulatta } \\
\text { (Rhesus macaque) } \\
3 \text { males }\end{array}$ & $\begin{array}{l}\text { Characterize striatal } \\
\text { dopamine release evoked } \\
\text { by STN DBS as a function } \\
\text { of stimulating and recording } \\
\text { electrode location. }\end{array}$ & $\begin{array}{l}\text { Triangular waveform from } \\
-0.4 \text { to }+1.5 \mathrm{~V} \text { at } 400 \mathrm{~V} / \mathrm{s} \\
\text { at } 10 \mathrm{~Hz}\end{array}$ & $\begin{array}{l}\text { Working electrode: } \mathrm{CFM}-7 \mu \mathrm{m} \\
\text { diameter and } 100 \mu \mathrm{m} \text { exposed tip. } \\
\text { Reference electrode: } \mathrm{Ag} / \mathrm{AgCl} \text { wire }\end{array}$ & $\begin{array}{l}\text { Evoked dopamine responses } \\
\text { were higher at the stimulation of } \\
\text { the dorsolateral posterior } \\
\text { border of the STN. }\end{array}$ \\
\hline
\end{tabular}


TABLE 1 | (Continued)

\begin{tabular}{|c|c|c|c|c|c|}
\hline Study & $\begin{array}{l}\text { Species (common } \\
\text { name), } n\end{array}$ & Goal & FSCV parameters & FSCV electrodes & Major findings \\
\hline $\begin{array}{l}\text { Ross et al., } \\
2016\end{array}$ & $\begin{array}{l}\text { Sus scrofa } \\
\text { domesticus (Swine) } \\
17 \text { (unspecified } \\
\text { number of males } \\
\text { and females) }\end{array}$ & $\begin{array}{l}\text { Determine the functional } \\
\text { connectivity between the } \\
\text { medial limbic and } \\
\text { corticolimbic circuits } \\
\text { following fornix DBS via } \\
\text { evoked-dopamine release } \\
\text { in the NAc. }\end{array}$ & $\begin{array}{l}\text { Triangular waveform from } \\
-0.4 \text { to }+1.5 \mathrm{~V} \text { at } 400 \mathrm{~V} / \mathrm{s} \\
\text { at } 10 \mathrm{~Hz}\end{array}$ & $\begin{array}{l}\text { Working electrode: CFM - } 7 \mu \mathrm{m} \\
\text { diameter and } 100 \mu \mathrm{m} \text { exposed tip. } \\
\text { Reference electrode: } \mathrm{Ag} / \mathrm{AgCl} \text { wire }\end{array}$ & $\begin{array}{l}\text { Electrical stimulation of the } \\
\text { fornix induced dopamine } \\
\text { release in the NAc and } \\
\text { increased BOLD activity in } \\
\text { structures along the } \\
\text { medial-corticolimbic circuitry. }\end{array}$ \\
\hline Lee et al., 2017 & $\begin{array}{l}\text { Rattus norvegicus } \\
\text { (Sprague-Dawley } \\
\text { rats) } 40 \text { males } \\
\text { Sus scrofa } \\
\text { domesticus (Swine) } \\
12 \text { males } \\
\text { Macaca mulatta } \\
\text { (Rhesus macaque) } \\
3 \text { males }\end{array}$ & $\begin{array}{l}\text { Demonstrate } \\
\text { proof-of-principle for } \\
\text { wireless measurement, } \\
\text { characterization, and } \\
\text { control of neurotransmitter } \\
\text { release. }\end{array}$ & $\begin{array}{l}\text { For dopamine and } \\
\text { adenosine - triangular } \\
\text { waveform from }-0.4 \text { to } \\
+1.5 \mathrm{~V} \text {; for serotonin - } \\
\mathrm{N} \text {-shaped waveform: }-0.4 \text {, } \\
+1.0,-0.4,+1.4 \mathrm{~V}\end{array}$ & $\begin{array}{l}\text { Working electrode: CFM - } 7 \mu \mathrm{m} \\
\text { diameter and } 100 \mu \mathrm{m} \text { exposed tip. } \\
\text { Reference electrode: } \mathrm{Ag} / \mathrm{AgCl} \text { wire }\end{array}$ & $\begin{array}{l}\text { Demonstrated successful } \\
\text { in vivo, wireless, single or } \\
\text { multi-channel detection of } \\
\text { dopamine, adenosine, and } \\
\text { serotonin, with integrated } \\
\text { sensing and stimulation } \\
\text { feedback capabilities. }\end{array}$ \\
\hline $\begin{array}{l}\text { Nakajima et al., } \\
2017\end{array}$ & $\begin{array}{l}\text { Macaca fuscata } \\
\text { (Japanese } \\
\text { macaques) } \\
3 \text { females }\end{array}$ & $\begin{array}{l}\text { Evaluate the effects of } \\
\text { clinically relevant STN and } \\
\text { GPi DBS in the modulation } \\
\text { of the activity of tonically } \\
\text { active striatal cholinergic } \\
\text { interneurons. }\end{array}$ & $\begin{array}{l}\text { Triangular waveform from } \\
-0.4 \text { to }+1.5 \mathrm{~V} \text { at } 408.6 \mathrm{~V} / \mathrm{s} \\
\text { at } 10 \mathrm{kHz} \text { for } 60 \mathrm{~s} \text {, and } \\
\text { resting potential at } 0 \mathrm{~V} \text {. }\end{array}$ & $\begin{array}{l}\text { Working electrode: SS insulated } \\
\text { CFM - 250-300 } \mu \mathrm{m} \text { exposed tip. } \\
\text { Reference electrode: } \mathrm{Ag} / \mathrm{AgCl} \text { wire }\end{array}$ & $\begin{array}{l}\text { STN DBS, but not GPi DBS, } \\
\text { induced striatal dopamine } \\
\text { release that was correlated to } \\
\text { increased activity of tonically } \\
\text { active cholinergic striatum } \\
\text { interneurons. }\end{array}$ \\
\hline $\begin{array}{l}\text { Schwerdt et al., } \\
2017 b\end{array}$ & $\begin{array}{l}\text { Macaca mulatta } \\
\text { (Rhesus macaque) } \\
3 \text { females }\end{array}$ & $\begin{array}{l}\text { Demonstrate the feasibility } \\
\text { of using an integrated } \\
\text { neurochemical modular } \\
\text { platform for monitoring } \\
\text { dopamine release from } \\
\text { sensors chronically } \\
\text { implanted in the brain of } \\
\text { non-human primates during } \\
\text { behavior and } \\
\text { stimulation-evoked } \\
\text { dopamine release. }\end{array}$ & $\begin{array}{l}\text { Triangular waveform from } \\
-0.4 \text { to }+1.3 \mathrm{~V} \text { at } 400 \mathrm{~V} / \mathrm{s} \\
\text { at } 10 \mathrm{~Hz}\end{array}$ & $\begin{array}{l}\text { Working electrode: Array of chronic } \\
\text { and acute fused silica insulated } \\
\text { CFMs }-7 \mu \mathrm{m} \text { diameter and } \\
\text { 150-300 } \mu \mathrm{m} \text { exposed tip } \\
\text { Reference electrode: Ag/AgCl wire } \\
\text { or SS electrode }\end{array}$ & $\begin{array}{l}\text { Modular platform allowed } \\
\text { measurements of dopamine } \\
\text { release from multiple sites in } \\
\text { the striatum while electrically } \\
\text { stimulating the SNc/NTA for up } \\
\text { to } 170 \text { days. }\end{array}$ \\
\hline $\begin{array}{l}\text { Settell et al., } \\
2017\end{array}$ & $\begin{array}{l}\text { Sus scrofa } \\
\text { domesticus (Swine) } \\
4 \text { (unspecified } \\
\text { number of males } \\
\text { and females) }\end{array}$ & $\begin{array}{l}\text { Determine the } \\
\text { neuromodulatory effects of } \\
\text { VTA DBS on dopamine } \\
\text { release in the NAc. }\end{array}$ & $\begin{array}{l}\text { Triangular waveform from } \\
-0.4 \text { to }+1.5 \mathrm{~V} \text {; or } \\
\text { N-shaped waveform: }-0.4 \text {, } \\
+1.0,-0.4,+1.4 \mathrm{~V}\end{array}$ & $\begin{array}{l}\text { Working electrode: CFM - } 7 \mu \mathrm{m} \\
\text { diameter and } 100 \mu \mathrm{m} \text { exposed tip. } \\
\text { Reference electrode: not specified }\end{array}$ & $\begin{array}{l}\text { VTA DBS resulted in increased } \\
\text { dopamine release in the NAC } \\
\text { and increased BOLD activity in } \\
\text { the striatum, cortical and limbic } \\
\text { structures. }\end{array}$ \\
\hline $\begin{array}{l}\text { Trevathan et al., } \\
2017\end{array}$ & $\begin{array}{l}\text { Rattus norvegicus } \\
\text { (Sprague-Dawley } \\
\text { rats) } \\
12 \text { females } \\
\text { Sus scrofa } \\
\text { domesticus (Swine) } \\
4 \text { males } \\
\text { Macaca mulatta } \\
\text { (Rhesus macaque) } \\
1 \text { male }\end{array}$ & $\begin{array}{l}\text { Characterize } \\
\text { subject-specific kinetics of } \\
\text { stimulation-evoked } \\
\text { dopamine release using } \\
\text { computational modeling. }\end{array}$ & $\begin{array}{l}\text { Triangular waveform from } \\
-0.4 \text { to }+1.5 \mathrm{~V} \text { at } 400 \mathrm{~V} / \mathrm{s} \\
\text { at } 10 \mathrm{~Hz}\end{array}$ & $\begin{array}{l}\text { Working electrode: CFM - } 7 \mu \mathrm{m} \\
\text { diameter and } 100 \mu \mathrm{m} \text { exposed tip. } \\
\text { Reference electrode: not specified }\end{array}$ & $\begin{array}{l}\text { Dopamine dynamics in } \\
\text { response to electrical } \\
\text { stimulation was modeled and } \\
\text { characterized based on } \\
\text { non-linear increased responses } \\
\text { of dopamine to increasing } \\
\text { SNcNTA stimulus intensity. }\end{array}$ \\
\hline
\end{tabular}

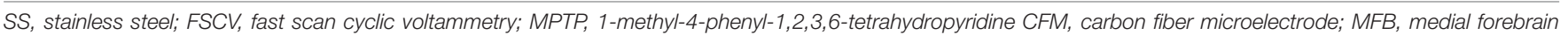

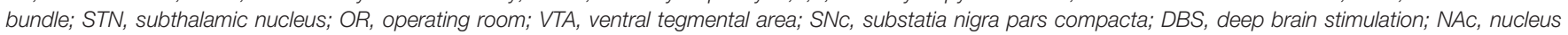
accumbens; BOLD, blood-oxygen-level-dependent imaging; and GPi, globus pallidus internum.

*See Table 3.

be attributed mainly to their small size, which is critical for minimizing damage to neural tissue and reducing the impact on neurochemical transmission near the electrode (see Figure 2 for CFM and DBS electrode leads size comparison). Similarly, CFM have shown good performance in maintaining normal neurotransmitter kinetics at the measurement site and high adsorption of neurotransmitters of interest (Borland et al., 2005;
Wang and Michael, 2012; Jaquins-Gerstl and Michael, 2015). However, despite their desirable neurochemical detection properties, CFMs are not optimal for clinical applications due to their high manufacturing variability (Roberts and Sombers, 2018) and fragility, which increase the risk of breakage during implantation into brain tissue (Schluter et al., 2014). Similarly, surface modified CFM made by coating with polymer films 
TABLE 2 | Characteristics of commonly used fast scan cyclic voltammetry working electrodes in in vivo studies.

\begin{tabular}{|c|c|c|c|c|c|}
\hline $\begin{array}{l}\text { Electrode } \\
\text { material }\end{array}$ & $\begin{array}{l}\text { Type of electrode } \\
\text { modification }\end{array}$ & Insulation & Advantages* & Disadvantages* & References \\
\hline Carbon fiber & $\mathrm{N} / \mathrm{A}$ & Borosilicate glass & $\begin{array}{l}\text { Ease of fabrication, low cost, } \\
\text { biocompatible, recommended } \\
\text { for acute recordings. }\end{array}$ & $\begin{array}{l}\text { Fragile, high risk of breakage, } \\
\text { poor fabrication uniformity, } \\
\text { susceptible to fouling. }\end{array}$ & $\begin{array}{l}\text { Patel et al., 2013; Bucher and } \\
\text { Wightman, 2015; Rodeberg } \\
\text { et al., 2017; Roberts and } \\
\text { Sombers, } 2018\end{array}$ \\
\hline Carbon fiber & $\mathrm{N} / \mathrm{A}$ & $\begin{array}{l}\text { Fused-silica capillaries } \\
\text { sealed with epoxy }\end{array}$ & $\begin{array}{l}\text { Good insulating properties, } \\
\text { increased flexibility, low cost, } \\
\text { lower risk of breakage, small } \\
\text { diameter, biocompatible, } \\
\text { recommended for chronic } \\
\text { recordings. }\end{array}$ & $\begin{array}{l}\text { Susceptible to fouling, poor } \\
\text { fabrication uniformity, torsion } \\
\text { applied to the carbon fiber not } \\
\text { well translated to the } \\
\text { fused-silica insulation. }\end{array}$ & $\begin{array}{l}\text { Clark et al., 2010; Rodeberg } \\
\text { et al., 2017; Roberts and } \\
\text { Sombers, } 2018\end{array}$ \\
\hline $\begin{array}{l}\text { Carbon } \\
\text { nanotube }\end{array}$ & Surface-modified CFM & $\begin{array}{l}\text { Borosilicate glass } \\
\text { or } \\
\text { Fused-silica capillaries } \\
\text { sealed with epoxy }\end{array}$ & $\begin{array}{l}\text { High mechanical strength, } \\
\text { improved electron-transfer } \\
\text { kinetics, high sensitivity to } \\
\text { adsorbed dopamine }\end{array}$ & $\begin{array}{l}\text { Poor fabrication uniformity and } \\
\text { reproducibility. }\end{array}$ & $\begin{array}{l}\text { Bucher and Wightman, 2015; } \\
\text { Ganesana et al., 2017; Yang } \\
\text { et al., } 2017\end{array}$ \\
\hline $\begin{array}{l}\text { Gold- } \\
\text { nanoparticles }\end{array}$ & Surface-modified CFM & $\begin{array}{l}\text { Borosilicate glass } \\
\text { or } \\
\text { Fused-silica capillaries } \\
\text { sealed with epoxy }\end{array}$ & $\begin{array}{l}\text { High electroactive surface area, } \\
\text { fast electron-transfer kinetics, } \\
\text { highly sensitive }\end{array}$ & Increased fouling & $\begin{array}{l}\text { Zhao et al., 2012; Mohanaraj } \\
\text { et al., } 2019\end{array}$ \\
\hline Carbon fiber & Nafion-coated CFM & $\begin{array}{l}\text { Borosilicate glass } \\
\text { or } \\
\text { Fused-silica capillaries } \\
\text { sealed with epoxy }\end{array}$ & $\begin{array}{l}\text { Improved selectivity and } \\
\text { sensitivity for dopamine, fast } \\
\text { response time }\end{array}$ & $\begin{array}{l}\text { Poor uniformity and } \\
\text { reproducibility in creating Nafion } \\
\text { film around the electrode, } \\
\text { fouling susceptibilibility is similar } \\
\text { to bare CFM. }\end{array}$ & $\begin{array}{l}\text { Brazell et al., 1987; Pihel et al., } \\
\text { 1996; Roberts and Sombers, } \\
2018\end{array}$ \\
\hline Carbon fiber & $\begin{array}{l}\text { PEDOT:Nafion-coated } \\
\text { CFM }\end{array}$ & $\begin{array}{l}\text { Borosilicate glass } \\
\text { or } \\
\text { Fused-silica capillaries } \\
\text { sealed with epoxy }\end{array}$ & $\begin{array}{l}\text { Improved selectivity and } \\
\text { sensitivity for dopamine, fast } \\
\text { response time, low fouling }\end{array}$ & $\begin{array}{l}\text { PEDOT is not approved for } \\
\text { human use }\end{array}$ & $\begin{array}{l}\text { Vreeland et al., 2015; } \\
\text { Ganesana et al., 2017; Boehler } \\
\text { et al., } 2020\end{array}$ \\
\hline Diamond & $\begin{array}{l}\text { Boron doped } \\
\text { conductive diamond }\end{array}$ & $\begin{array}{l}\text { Borosilicate glass } \\
\text { sealed with resin } \\
\text { or } \\
\text { Stainless tube sealed } \\
\text { with resin } \\
\text { or } \\
\text { Parylene }\end{array}$ & $\begin{array}{l}\text { Wide potential window, low and } \\
\text { stable background current, low } \\
\text { fouling, improved longevity and } \\
\text { resistance }\end{array}$ & $\begin{array}{l}\text { Low sensitivity, slow } \\
\text { electron-transfer kinetics, costly } \\
\text { fabrication, poor doping may } \\
\text { lead to impurities on the surface }\end{array}$ & $\begin{array}{l}\text { Yoshimi et al., 2011; Patel } \\
\text { et al., 2013; Bennet et al., } \\
\text { 2016; Ganesana et al., 2017; } \\
\text { Chang et al., } 2019\end{array}$ \\
\hline Platinum & Metal & Unknown & $\begin{array}{l}\text { Less susceptible to breakage, } \\
\text { versatile for surface } \\
\text { modification and assembly into } \\
\text { arrays for } \\
\text { multi-neurotransmitter } \\
\text { monitoring }\end{array}$ & $\begin{array}{l}\text { Susceptible to corrosion, } \\
\text { passivation, } \\
\text { increased fouling, low } \\
\text { sensitivity. }\end{array}$ & $\begin{array}{l}\text { Jackowska and Krysinski, } \\
\text { 2013; Roberts and Sombers, } \\
2018\end{array}$ \\
\hline Gold & Metal & Unknown & $\begin{array}{l}\text { Less susceptible to breakage, } \\
\text { versatile for surface } \\
\text { modification and assembly into } \\
\text { arrays or miniature gold } \\
\text { electrodes, good sensitivity to } \\
\text { catecholamines, }\end{array}$ & $\begin{array}{l}\text { Susceptible to corrosion, } \\
\text { passivation, } \\
\text { increased fouling, low sensitivity }\end{array}$ & $\begin{array}{l}\text { Zachek et al., 2008; Jackowska } \\
\text { and Krysinski, 2013; Roberts } \\
\text { and Sombers, } 2018\end{array}$ \\
\hline
\end{tabular}

CFM, Carbon Fiber Microelectrode; PEDOT, poly(3,4-ethylenedioxythiophene).

${ }^{*}$ Relative to borosilicate glass CFM.

such as Nafion and PEDOT provides enhanced sensitivity, selectivity, and kinetic properties for dopamine detection. However, electrode reproducibility is still poor due to the lack of coating uniformity (Brazell et al., 1987; Pihel et al., 1996; Vreeland et al., 2015; Ganesana et al., 2017; Roberts and Sombers, 2018). In addition, PEDOT is not currently approved for clinical use due to the large range of PEDOT variations determined by multiple factors such as the fabrication technique, the dopant, and the functionalization of the polymer (Boehler et al., 2020).
As an alternative to CFM and surface modified CFM, several groups have attempted to develop Boron-doped diamond (BDD) electrodes, which offer increased strength and longevity compared to CFM (Martin et al., 1998; Suzuki et al., 2007; Yoshimi et al., 2015; Bennet et al., 2016). However, BDD has distinct electrochemical properties and significant characterization studies must be performed to better understand and optimize BDD for neurochemical sensing in the clinical setting. To date, studies have shown that BDD electrodes are not suitable for chronic in vivo neurochemical detections due 


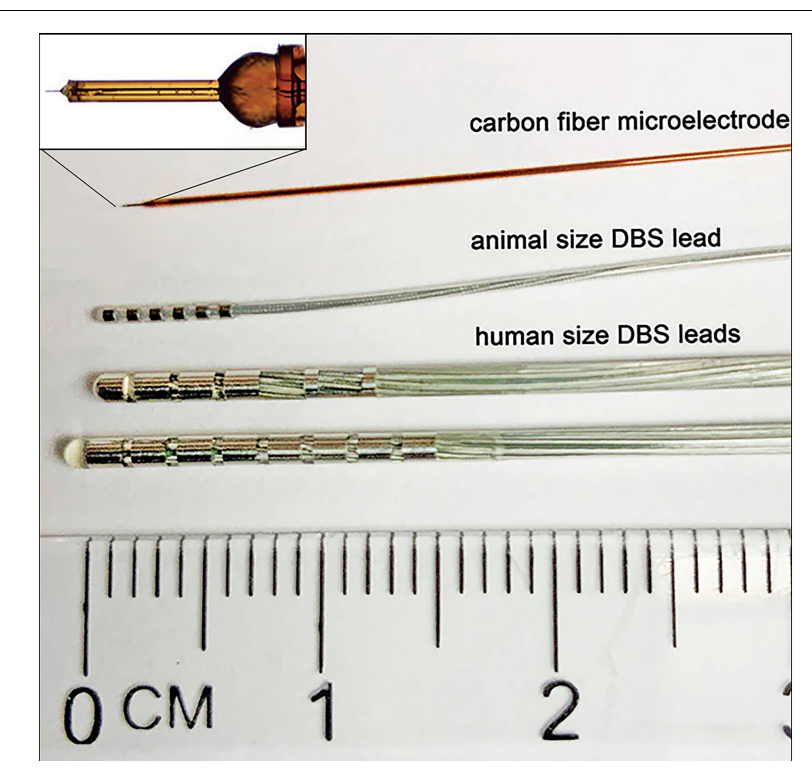

FIGURE 2 | Comparison between typically used FSCV working electrode and DBS electrode leads. From top to bottom: In-house made epoxy and silica tubing-insulated CFM for detection of neurotransmitters via FSCV; Animal size 6-contact DBS electrode lead - NuMED, Inc. (2.0 Fr shaft, $0.5 \mathrm{~mm}$ spacing, and $42 \mathrm{~cm}$ length); Human size DBS electrode leads - Boston Scientific, Inc. Vercise DBS Directional Lead, $6.0 \mathrm{~mm}^{2}$ dome tip contact surface area, $1.5 \mathrm{~mm}^{2}$ segmented contacts surface area, $6.0 \mathrm{~mm}^{2}$ ring contacts surface area, $1.5 \mathrm{~mm}$ contact length, $2.0 \mathrm{~mm}$ spacing, $1.3 \mathrm{~mm}$ diameter, $30-45 \mathrm{~cm}$ length; and Vercise DBS lead, $1.5 \mathrm{~mm}$ contact length, $2.0 \mathrm{~mm}$ spacing, $1.3 \mathrm{~mm}$ diameter, $30-45 \mathrm{~cm}$ length).

to poor sensitivity and neurochemical adsorption rate, increased fouling, and distorted signals (Yoshimi et al., 2011; Jackowska and Krysinski, 2013; Chang et al., 2019).

Metal electrodes such as Gold and Platinum electrodes provide increased mechanical strength being more resistant to breakage during implantation. Additionally, these materials allow for novel electrode arrays and the capability of multiple neurotransmitter simultaneous detection. However, metal electrodes are hardly used for clinical applications because of the risk of corrosion that can lead to tissue damage, passivation and increased biofouling that interfere with neurotransmitter detection (Zachek et al., 2008; Jackowska and Krysinski, 2013; Roberts and Sombers, 2018).

Although novel electrode materials or configurations, such as Platinum, Gold, and Nafion-coated CFM described above, provide numerous benefits, the representation of signal and artifacts in vitro and in vivo can vary significantly to those measured with CFMs (Bucher and Wightman, 2015). For this reason, it is important to fully validate novel working electrode designs via large animal experiments with similar signal levels and experimental paradigms to anticipated human studies.

\section{Reference Electrode Biocompatibility and Stability}

Reference electrodes are pivotal to ensure stable, consistent, and neurotransmitter-specific measurements. Reference electrodes should not be polarized (i.e., pulled away from their open circuit potential) during FSCV to avoid sensor drift, low signal-to-noise ratio, and distorted neurochemical signals (Rodeberg et al., 2017). Thus, investigators need to ensure that polarization is avoided by increasing the surface area of the reference electrodes relative to the active CFM, as well as by using materials that have a stable in vivo reference potential and low polarizability properties. Reference electrodes for in vivo neurotransmitter measurements in animal models are typically made of $\mathrm{Ag} / \mathrm{AgCl}$, which are highly cytotoxic making them unsafe for long-term (in the order of hours/days) human use (Hashemi et al., 2011; Kolli et al., 2015; Seaton et al., 2020). To avoid the safety concerns associated with $\mathrm{Ag} / \mathrm{AgCl}$ electrodes, stainless steel (SS) reference electrodes have been used in humans (Kishida et al., 2011; Bucher and Wightman, 2015). Unfortunately, SS is highly polarizable and has an inhomogeneous grain structure that decreases the stability of its open circuit potential by changing the protein adsorption to the electrode surface, which can shift its open circuit potential (Rajendrachari, 2018). The use of SS reference electrodes for clinical FSCV (see Table 3) is an unresolved confound that can significantly affect measurement sensitivity and specificity. Thus, there is a critical need for the pre-clinical investigation and validation of novel reference electrodes that are not only biocompatible, but also that provide stable reference potentials prior to human use.

\section{Tissue Damage and Signal Integrity}

Implantation of both working and reference electrodes disrupts the blood-brain barrier, triggering a cascade of complex molecular and cellular responses such as activation of glial cells, loss of perfusion, secondary metabolic injury, neuronal degeneration, and introduction of mechanical strain, which can affect neurochemical sensing (Woolley et al., 2013; Kozai et al., 2015). For example, studies have shown that brain hemorrhage associated with electrode implantation in the human brain can result in 1-2\% of symptomatic hemorrhage (i.e., speech arrest, hemiplegia, agitation, and confusion) and $0.5-0.9 \%$ of permanent neurological deficit (Sansur et al., 2007; Park et al., 2011). Therefore, any clinical FSCV work should minimize the risks associated with mechanical tissue damage through rigorous preclinical studies aimed at understanding and reducing mechanical damage to neural tissue (ISO10993-6:2016, 2016).

Reduction/oxidation (redox) reactions can also disrupt neurochemical diffusion to the region of the sensing electrode, changing neurochemical concentrations near the electrode and affecting detection of the neurochemical species of interest (Wang and Michael, 2012; Jaquins-Gerstl and Michael, 2015).

Carbon fiber microelectrodes used in pre-clinical studies have traditionally been fabricated from silica glass capillaries or tubing with a small implantation profile (Bucher and Wightman, 2015; Rodeberg et al., 2017). However, clinical FSCV studies have mimicked setups used clinically to implant electrophysiological sensing electrodes and relied on stainless steel cannulas to implant either CFM or diamond electrodes, e.g., FHC\#66IT(AO6) $165 \mathrm{~mm}$ SS insertion tube for placing depth electrodes along a trajectory. The effect of the relatively large tissue insult 
TABLE 3 | FSCV studies in humans.

\begin{tabular}{|c|c|c|c|c|}
\hline Study & Goal & FSCV parameters & FSCV electrodes & Major findings \\
\hline $\begin{array}{l}\text { Kishida et al., } \\
2011\end{array}$ & $\begin{array}{l}\text { Demonstrate feasibility of } \\
\text { sub-second dopamine } \\
\text { detection in humans during } \\
\text { brain surgery. }\end{array}$ & $\begin{array}{l}\text { Triangular } \\
\text { waveform from } \\
-0.425 \mathrm{~V} \text { to }+1.380 \text { at } \\
400 \mathrm{~V} / \mathrm{s} \text { at } 10 \mathrm{~Hz} \text {. }\end{array}$ & $\begin{array}{l}\text { Working electrode: Glass insulated } \\
7 \mu \mathrm{m} \text { CFM } \\
\text { Reference electrode: Stainless steel }\end{array}$ & $\begin{array}{l}\text { First demonstration of real-time human } \\
\text { dopamine release measured during a } \\
\text { behavioral investment task. }\end{array}$ \\
\hline $\begin{array}{l}\text { Chang et al., } \\
2012\end{array}$ & $\begin{array}{l}\text { Quantify adenosine } \\
\text { concentrations in human } \\
\text { subjects with essential tremor } \\
\text { during VIM DBS. }\end{array}$ & $\begin{array}{l}\text { Triangular } \\
\text { waveform from } \\
-0.4 \mathrm{~V} \text { to }+1.5 \text { at } \\
400 \mathrm{~V} / \mathrm{s} \text { at } 10 \mathrm{~Hz} \text {. }\end{array}$ & $\begin{array}{l}\text { Working electrode: Glass and } \\
\text { polyamide insulated } 7 \mu \mathrm{m} \text { CFM with } \\
50 \mu \mathrm{m} \text { exposed tip or silicone insulated } \\
30 \mu \mathrm{m} \text { CFM } \\
\text { Reference electrode: Stainless steel }\end{array}$ & $\begin{array}{l}\text { Demonstrated changes in extracellular } \\
\text { concentrations of adenosine in the VIM of } \\
\text { patients undergoing VIM DBS. }\end{array}$ \\
\hline $\begin{array}{l}\text { Van Gompel } \\
\text { et al., } 2014\end{array}$ & $\begin{array}{l}\text { Determine changes in } \\
\text { extracellular adenosine } \\
\text { concentration during epileptic } \\
\text { activity (in swine and humans).* }\end{array}$ & $\begin{array}{l}\text { Triangular } \\
\text { waveform from } \\
-0.4 \mathrm{~V} \text { to }+1.5 \text { at } \\
400 \mathrm{~V} / \mathrm{s} \text { at } 10 \mathrm{~Hz} \text {. }\end{array}$ & $\begin{array}{l}\text { Working electrode: Glass insulated } \\
7 \mu \mathrm{m} \text { CFM } \\
\text { Reference electrode: Stainless steel, } 24 \\
\text { gage }\end{array}$ & $\begin{array}{l}\text { Extracellular adenosine concentration } \\
\text { increases prior to seizure termination. }\end{array}$ \\
\hline $\begin{array}{l}\text { Bennet et al., } \\
2016\end{array}$ & $\begin{array}{l}\text { Demonstrate sensitivity of } \\
\text { diamond-based electrode to } \\
\text { detect and quantify } \\
\text { neurotransmitter release in } \\
\text { human patients undergoing } \\
\text { DBS. }\end{array}$ & $\begin{array}{l}\text { Triangular } \\
\text { waveform from } \\
-0.4 \mathrm{~V} \text { to }+1.5 \text { at } \\
400 \mathrm{~V} / \mathrm{s} \text { at } 10 \mathrm{~Hz} \text {. }\end{array}$ & $\begin{array}{l}\text { Working electrode: Parylene-C coated } \\
\text { boron-doped diamond, conical shape, } \\
50 \mu \mathrm{m} \text { at the base and } 100 \mu \mathrm{m} \text { long. } \\
\text { Reference electrode: Stainless steel }\end{array}$ & $\begin{array}{l}\text { Dopamine and adenosine release were } \\
\text { detected using boron-doped diamond } \\
\text { electrode in human patients undergoing } \\
\text { DBS for tremor. }\end{array}$ \\
\hline $\begin{array}{l}\text { Kishida et al., } \\
2016\end{array}$ & $\begin{array}{l}\text { Determine whether subsecond } \\
\text { dopamine fluctuations in the } \\
\text { human striatum encode reward } \\
\text { prediction errors during a } \\
\text { sequential choice task. }\end{array}$ & $\begin{array}{l}\text { Triangular waveform from }-0.6 \\
\text { to }+1.4 \mathrm{~V} \text { at } 400 \mathrm{~V} / \mathrm{s} \text { at } 10 \mathrm{~Hz} \text {. }\end{array}$ & $\begin{array}{l}\text { Working electrode: } 7 \text { } \mu \mathrm{m} \text { CFM } \\
\text { insulated with a polyimide-coated } \\
\text { fused-silica capillary } \\
\text { Reference electrode: Stainless steel }\end{array}$ & $\begin{array}{l}\text { Demonstrated striatal dopamine changes } \\
\text { encoding experience-dependent reward } \\
\text { prediction error and counterfactual } \\
\text { prediction error. }\end{array}$ \\
\hline $\begin{array}{l}\text { Lohrenz et al., } \\
2016\end{array}$ & $\begin{array}{l}\text { Compare BOLD activity and } \\
\text { dopamine responses during a } \\
\text { sequential choice task in } \\
\text { humans. }\end{array}$ & $\begin{array}{l}\text { Triangular waveform from }-0.6 \\
\text { to }+1.4 \mathrm{~V} \text { at } 400 \mathrm{~V} / \mathrm{s} \text { at } 10 \mathrm{~Hz} \text {. }\end{array}$ & $\begin{array}{l}\text { Working electrode: } 7 \text { } \mu \mathrm{m} \text { CFM } \\
\text { insulated with a polyimide-coated } \\
\text { fused-silica capillary } \\
\text { Reference electrode: Stainless steel }\end{array}$ & $\begin{array}{l}\text { Demonstrated non-linear relationship } \\
\text { between BOLD activity and dopamine } \\
\text { release of subjects performing an } \\
\text { investment task. }\end{array}$ \\
\hline $\begin{array}{l}\text { Moran et al., } \\
2018\end{array}$ & $\begin{array}{l}\text { Demonstrate changes in the } \\
\text { serotonergic signaling during a } \\
\text { decision making task. }\end{array}$ & $\begin{array}{l}\text { Triangular waveform from }-0.6 \\
\text { to }+1.4 \mathrm{~V} \text { at } 400 \mathrm{~V} / \mathrm{s} \text { at } 10 \mathrm{~Hz} \text {. }\end{array}$ & $\begin{array}{l}\text { Working electrode: } 7 \mu \mathrm{m} \text { CFM } \\
\text { insulated with a polyimide-coated } \\
\text { fused-silica capillary } \\
\text { Reference electrode: Stainless steel }\end{array}$ & $\begin{array}{l}\text { Striatal serotonin correlates with decisions } \\
\text { in a sequential investment game and may } \\
\text { encode a strategy that modulates choice } \\
\text { selection to mitigate risk. }\end{array}$ \\
\hline $\begin{array}{l}\text { Montague and } \\
\text { Kishida, } 2018\end{array}$ & $\begin{array}{l}\text { Demonstrate a new approach } \\
\text { for simultaneous } \\
\text { multi-neurotransmitter } \\
\text { detection and quantification. }\end{array}$ & $\begin{array}{l}\text { Triangular waveform from }-0.6 \\
\text { to }+1.4 \mathrm{~V} \text { at } 400 \mathrm{~V} / \mathrm{s} \text { at } 10 \mathrm{~Hz} \text {. }\end{array}$ & $\begin{array}{l}\text { Working electrode: } 7 \mu \mathrm{m} \text { CFM } \\
\text { insulated with a polyimide-coated } \\
\text { fused-silica capillary } \\
\text { Reference electrode: Stainless steel }\end{array}$ & $\begin{array}{l}\text { The elastic net approach extracted a } \\
\text { concentration-prediction model for multiple } \\
\text { analytes that included dopamine, serotonin, } \\
\text { and norepinephrine. }\end{array}$ \\
\hline
\end{tabular}

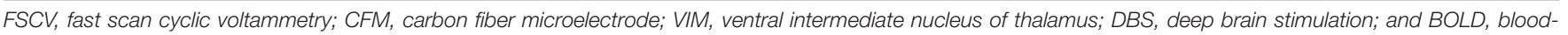
oxygen-level-dependent imaging.

*See Table 1.

resulting from cannula insertion on measured FSCV signals is not well understood and should be explored in large animal models.

\section{Spatial Resolution and Heterogeneity of Neurotransmitter Release}

The high spatial resolution of FSCV, determined by the size of the working electrode relative to the volume of neurochemical release, is one of the driving motivators for use of FSCV to detect neurochemical signaling. Working electrodes are typically made from 7 to $30 \mu \mathrm{m}$ diameter carbon fibers cut to $50-500 \mu \mathrm{m}$ lengths (see Figure 2). It is the small size of the CFM that allows for rapid scan rates $(>100 \mathrm{~V} / \mathrm{s})$ which enables neurotransmitter measurements on a subsecond timescale without producing large charging currents potentially harmful to the brain tissue (Zachek et al., 2009). The spatial resolution of the CFM is on the order of tens to hundreds of microns (Rodeberg et al., 2017), much higher than microdialysis (Jaquins-Gerstl and Michael, 2015) and functional imaging (Glover, 2011). FSCV high spatial resolution allows for neurotransmitter measurement in discrete brain regions, which could potentially serve as guidance for improved targeting of DBS electrode implantation.

It must be considered that studies have shown inconsistent dopamine kinetics across different microdomains in small and large animal models (Wightman et al., 2007; Moquin and Michael, 2009; Taylor et al., 2015), which can lead to data misinterpretation and demonstrate that FSCV recordings from a single CFM are not adequate for testing specific hypotheses of systemic neurotransmission. Thus, measurements obtained at these high resolutions may not accurately represent activity within the target brain nuclei due to sparse synaptic organization, neuronal heterogeneity, and differences in neurochemical release kinetics throughout the structures of interest. These inconstancies in neurotransmitter release across a target of interest, coupled with limited recording time in the operating room, can make finding a suitable recording site difficult for clinical studies. Sparsity and heterogeneity can be addressed by developing FSCV electrode arrays capable of simultaneously 
sampling multiple brain regions (Zachek et al., 2010; Patel et al., 2016; Schwerdt et al., 2017a). This, however, comes at the expense of increased risk of hemorrhage and inflammation, which must be weighed carefully against the expected benefit of the study.

\section{Effects of Sterilization of Fast Scan Cyclic Voltammetry Electrodes on Recorded Signals}

Sterilization of implantable devices is paramount to reduce the risk of infection. However, this creates a challenge for FSCV measurements as sterilization procedures can alter the geometrical and chemical surface of the CFM, compromise electrode insulation, affect electrical connections, and ultimately, hinder biocompatibility (Nair, 1995; Godara et al., 2007; Zheng et al., 2011; Chong et al., 2015). For example, CFM working electrodes and $\mathrm{Ag} / \mathrm{AgCl}$ reference electrodes are composed of heat-sensitive materials, which makes steam and dry heat sterilization inappropriate because these techniques can cause polymer degradation and changes in physical or mechanical properties (Nair, 1995; Mendes et al., 2007). Thus, sterilization procedures should not only be evaluated for sterility prior to clinical use, but also for the effect of surface modification on signal specificity and accuracy.

\section{Effects of the Operating Room Environment on Recorded Signals}

Continuous electrochemical recording is associated with baseline instability and sensor drift as a function of time, ultimately reducing measurement accuracy and reproducibility (DeWaele et al., 2017; Mitchell et al., 2017). This drift can be caused by a myriad of external factors such as temperature fluctuations, changes in the chemical environment, or chemical reactions at the sensing surface (Roberts and Sombers, 2018). The chemical environment can be affected by biofouling caused by extracellular proteins, redox reaction debris, cellular encapsulation around the surface of the electrode, and many other factors (Kachoosangi and Compton, 2007; Patel et al., 2013; Nicolai et al., 2017; Seaton et al., 2020). To minimize these effects, several strategies such as sensor cleaning, recalibration, and even replacement have been used (Hermans et al., 2008; DeWaele et al., 2017; Mitchell et al., 2017). However, these are not feasible in an intraoperative setting, where available time is limited. Additionally, the relatively long period of stabilization following implantation of an FSCV electrode (Ramsson et al., 2015; Rodeberg et al., 2017; Castagnola et al., 2020) limits the time available for data collection in the operating room. Furthermore, the operating room environment has numerous sources of noise. These are known to affect electrophysiological recordings, but their effects have not been characterized for electrochemical measurements using FSCV.

\section{Challenges for Data Analysis}

One of the most challenging aspects of FSCV is the complex and variable nature of the data (Olivieri, 2008; Johnson et al., 2016). Signals obtained in vivo often have contributions from multiple analytes that require resolution prior to positive identification and quantification. Consistency and accuracy can be improved with automated multivariate statistical data analyses, such as principal component regression, partial least squares regression, and statistical models. Typically, information across the scanpotential window can be used to separate overlapping signals by using training sets (i.e., signals obtained from electrodes, recording sessions, and/or subjects other than those used for experimental data collection) as calibration models (Johnson et al., 2016, 2017; Kishida et al., 2016; Lohrenz et al., 2016; Rodeberg et al., 2017; Meunier et al., 2018). The effectiveness of these analysis techniques depends on the existence of wellcharacterized relationships between the potential at the working electrode and the measured redox currents for the neurochemical species of interest. For clinical FSCV, analysis algorithms should be validated in vivo using the exact recording setup that will be used clinically, at signal levels comparable to those normally observed in pre-clinical settings.

Recent studies adopted a data analysis algorithm built from a novel statistical model trained on in vitro data recorded against $\mathrm{Ag} / \mathrm{AgCl}$ reference electrodes. However, the algorithm was applied to data recorded using SS reference electrodes in patients during a task performed in the operating room without previous pre-clinical validation (Kishida et al., 2011; Montague and Kishida, 2018). Pre-clinical validation using the Five Golden Rules afore mentioned should be performed prior to clinical use of any analysis algorithms. Thus, algorithms such as the one described above remains largely unvalidated until it is tested both in vitro and in vivo in a pre-clinical model using the same type of working and reference electrodes as those that will be used clinically.

\section{OTHER CONSIDERATIONS AND TECHNICAL CHALLENGES TO FAST SCAN CYCLIC VOLTAMMETRY IN HUMANS}

\section{Patient Safety}

Patient safety is paramount whenever clinical studies are performed. As with all clinical studies, the onus of determining safety risk lies with the investigator and local IRB, regardless of whether the study involves the use of a device subjected to an Investigational Device Exemption or not (Code of Federal Regulations, 2021a). While not all risk can be eliminated, it is the responsibility of the investigator and local IRB to create a risk management process in order to identify, isolate, and mitigate as much risk as possible (ISO14971:2019, 2019). In this way, not only is the well-being of the patient protected, but also is the integrity, rigor, and reproducibility of the collected data and resulting conclusions.

\section{Material Biocompatibility}

Any material or device that comes into contact with tissue, especially neural tissue, in a clinical study should be evaluated for biocompatibility. Although extensive discussion of biocompatibility testing is outside of the scope of this work, guidance for this biocompatibility testing is provided by the 


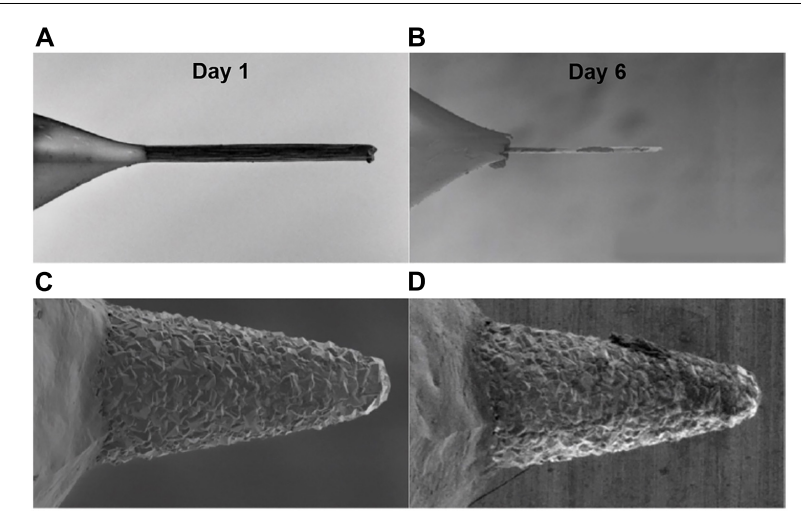

FIGURE 3 | Impact of FSCV waveform on CFM and BDD electrodes longevity. Scanning electron microscope images demonstrate the surface erosion of CFMs $(\mathbf{A}, \mathbf{B})$ and BDDs $(\mathbf{C}, \mathbf{D})$ on day $1(\mathbf{A}, \mathbf{C})$ and day $6 \mathbf{( B , D )}$ of continuous FSCV. CFMs were significantly eroded after 6 days of continuous FSCV while BDD electrodes show no noticeable changes. A FSCV triangular waveform from -0.4 to $1.5 \mathrm{~V}$ and back to $-0.4 \mathrm{~V}$ at $10 \mathrm{~Hz}$ at $400 \mathrm{~V} / \mathrm{s}$ was continuously applied to CFMs and BDDs immersed in Tris buffer over an extended period of time. Adapted from Bennet et al. (2016).

ISO 10993 standard (ISO10993-1:2018, 2018). It is important to note that even if the material itself is biocompatible, there is a risk of harmful substances to be present on the material as byproducts of manufacturing or other processing steps. In commercially marketed medical devices, these risks are mitigated by manufacturing under Good Manufacturing Practice protocols (Code of Federal Regulations, 2021b), which help control any deviation between manufacturing batches. Currently, no medical device suppliers provide electrodes for FSCV, so it falls on the investigator to ensure consistency between materials tested for biocompatibility and those that are used for clinical FSCV work.

\section{Electrochemical Reactions Due to Waveform Selection}

Different electrode materials exhibit unique electrochemical properties that may lead to changes in the waveforms that are used for neurochemical detection. These waveforms, in turn, affect the various safety considerations listed above. Thus, testing of the electrical FSCV potential waveforms is required to determine the range of voltages that can be safely applied to the tissue without inducing excitotoxicity, electrolysis, and reduced electrode longevity. For example, harmful reactive oxygen species are generated when oxygen is reduced (negative potentials) or when water is oxidized (positive potentials; Roberts and Sombers, 2018). However, the potential at which these redox reactions occur varies depending on the water window for the specific electrode material. For voltage-controlled applications such as FSCV, the water window informs whether a particular waveform will result in electrolysis, which is damaging to tissue (Cogan et al., 2004; Cogan, 2008). Therefore, all FSCV waveforms used should be evaluated for tissue damage and safety for each electrode material and configuration should be stablished.

It is also vital to ensure that the waveform does not damage the electrode itself, as material dissolution is detrimental to the longevity of the electrode (Figure 3) and the released particulate could be harmful to tissue. To prevent electrode damage, the largest potentials of a waveform should be applied to the electrode in solution in a closed-system benchtop setup over an extended period of time and optionally, at a higher frequency than planned. The beaker solution should be sampled at regular intervals and can be tested with mass spectrometry to determine whether the electrode material is dissolved into solution (Boehler et al., 2020). Subsequent biological tests should be conducted to determine whether the intended waveforms would damage cells due to excitotoxicity by conducting safety tests of electrical stimulation in neural tissue

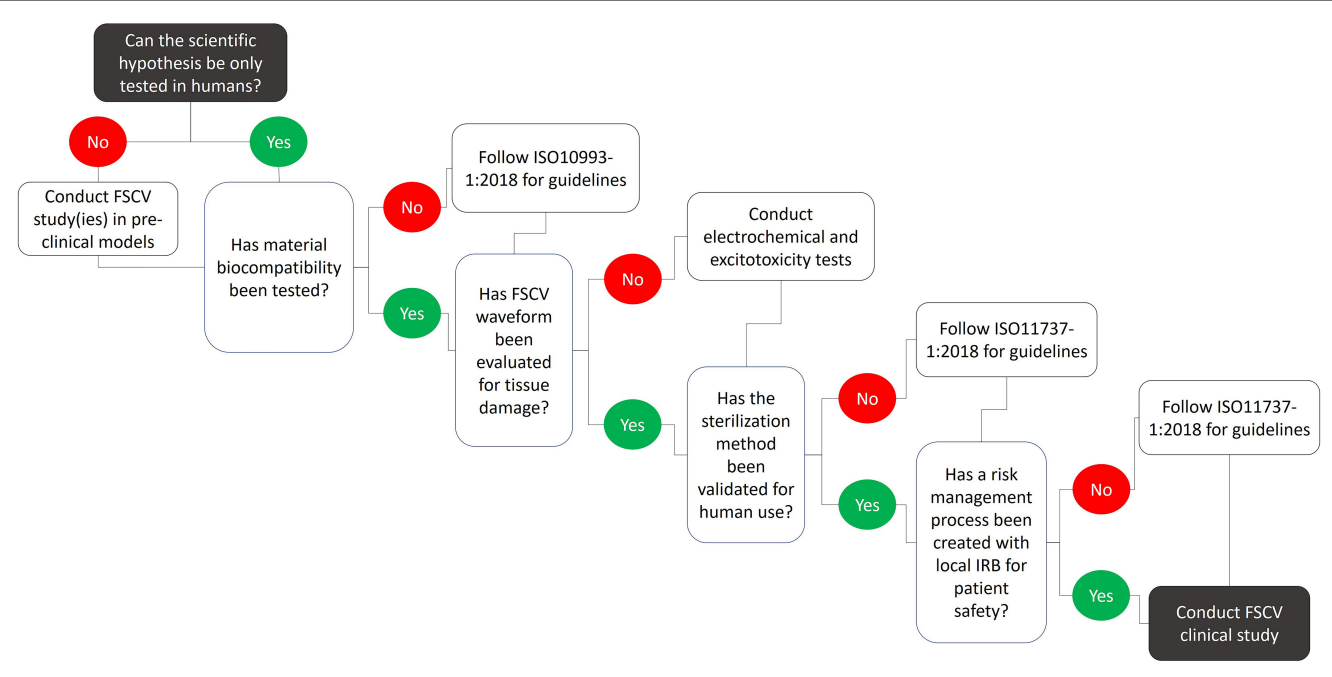

FIGURE 4 | Technical considerations and recommendations for conducting FSCV studies in humans. Numerous limitations associated with FSCV limit the type and number of scientific questions that can be answered by clinical FSCV studies. These limitations pose safety risks to the patient and need to be addressed prior to the clinical use of FSCV. Extensive pre-clinical testing including material biocompatibility, waveform safety, tissue damage, and sterilization methods must be conducted following specific guidelines in order to develop a risk management process in cooperation with local IRBs to establish patient safety. 
(McCreery et al., 1988, 1990, Robblee and Rose, 1990; Shannon, 1992). Finally, pre-clinical studies with thorough histological evaluation of tissue adjacent to and in the vicinity of the implanted electrode should be conducted prior to human studies (Cogan et al., 2004, 2016).

\section{Sterilization Validation}

As would be expected for any invasive medical device, sterilization validation is essential to patient safety (ISO11737$1: 2018,2018)$. Balancing this need with that of ensuring electrode integrity may require exploration of novel sterilization methods. As previously discussed, the heat-sensitive nature of some of the components commonly used for FSCV electrodes, steam or dry heat sterilization methods are not viable (Nair, 1995; Mendes et al., 2007). However, sterilization methods that do not rely on heat pose other challenges to patient safety. For example, $\gamma$ radiation generates free radicals that can cause tissue damage (Ries et al., 1996; Gorna and Gogolewski, 2003; Mendes et al., 2007). Similarly, ethylene oxide and its derivatives have been reported to accumulate in some materials, potentially increasing teratogenicity risk (Lucas et al., 2003; Mendes et al., 2007). As previously mentioned, the investigator should characterize and validate each sterilization technique for each FSCV sensor type, composition, and geometry to ensure patient safety, in addition to signal accuracy.

\section{DISCUSSION}

Many of the safety and efficacy concerns associated with FSCV recordings in humans are due to interrelated technical challenges, which makes these challenges difficult to address. However, once the scientific and clinical benefits of the study are clearly defined and the risks to patient safety minimized, residual risks can be weighed against anticipated benefits. This risk-benefit analysis is crucial to the success of the clinical work.

Investigators should perform a compelling risk/benefit analysis to justify the clinical use of FSCV, ensure scientific rigor, and articulate the scientific and clinical benefit of FSCV studies. Addressing and mitigating risk to patient safety will help ensure patients are not put at undue risk. Of course, not all risk can be eliminated, and it is this remaining risk that must be weighed against the proposed clinical benefit. Furthermore, it is essential that both risks and benefits are appropriately and timely communicated to patients through consent forms so patients can make an informed decision about their participation.

Risk-benefit analyses are complex, so the authors propose that the FSCV community develop the necessary guidelines through partnership with the FDA to engender high-quality scientific discoveries that FSCV can offer.

Clinical studies need not demonstrate that FSCV provides direct patient benefit. However, evidence from pre-clinical studies should be used to guide approval for use in human subjects. Application of FSCV in clinical studies should be carefully evaluated to ensure that only hypothesis-driven studies that cannot be appropriately and methodically performed in animal models are conducted in human subjects. Thus, translational FSCV research should demonstrate scientific rationale, feasibility, efficacy, and safety prior to attempting clinical application.

While progress has been made in the clinical use of FSCV (Table 3), it must be stressed that electrode safety and data robustness have yet to be characterized. To date, clinical FSCV studies have employed working and reference electrodes and signal processing techniques that have not been validated by translational research. The Five Golden Rules are not directly applicable in the clinical setting. Thus, the operating room environment necessitates the reconsideration of human FSCV methodologies. Specifically, the following processes need to be performed: acute and chronic target assessment and confirmation, standardization of electrode manufacturing processes, signal verification in human recordings, and characterization of sources of electrical noise in the intraoperative environment. Addressing these issues will facilitate application of FSCV in the clinical setting, particularly if FDA-approved working and reference electrodes become commercially available.

The use of FSCV in humans must be understood as a clinical intervention, and as such, should follow the same protocols and guidelines required by the FDA to establish device safety (Figure 4). Additionally, there are many gaps in knowledge that complicate the risk/benefit analysis for the clinical use of FSCV during existing surgical procedures. Until these gaps are addressed, the likelihood of obtaining useful scientifically rigorous data is low due to all the unknowns and the quality of the recorded signal in the operating room environment. Thus, clinical FSCV should only be performed when there is a clear hypothesis that can further neuroscientific understanding in the pursuit of improved therapeutic interventions, and only after all risk factors discussed in this manuscript have been mitigated.

\section{AUTHOR CONTRIBUTIONS}

SLB, JT, SH, and JLL contributed to the conceptualization and design of this work. SLB, JT, and SH wrote the first draft. AA wrote sections of this work. SLB was responsible for the project administration and supervision. JLL supervised the project. All authors contributed to manuscript revision, read, and approved the submitted version review and editing.

\section{FUNDING}

This work was supported by the National Institutes of Health, NINDS (R01 NS084975 award to JLL) and The Grainger Foundation.

\section{ACKNOWLEDGMENTS}

We thank Kai Miller for providing human size deep brain stimulation electrode lead (Boston Scientific, Inc., Vercise DBS electrode lead) used in Figure 2. 


\section{REFERENCES}

Adams, R. N. (1976). Probing brain chemistry with electroanalytical techniques. Anal. Chem. 48, 1126A-1138A. doi: 10.1021/ac50008a001

Ariansen, J., Heien, M. L. A. V., Hermans, A., Phillips, P. E. M., Hernadi, I., Bermudez, M., et al. (2012). Monitoring extracellular pH, oxygen, and dopamine during reward delivery in the striatum of primates. Front. Behav. Neurosci. 6:36. doi: 10.3389/fnbeh.2012.00036

Bennet, K. E., Tomshine, J. R., Min, H.-K., Manciu, F. S., Marsh, M. P., Paek, S. B., et al. (2016). A diamond-based electrode for detection of neurochemicals in the human brain. Front. Hum. Neurosci. 10:102. doi: 10.3389/fnhum.2016.00102

Boehler, C., Carli, S., Fadiga, L., Stieglitz, T., and Asplund, M. (2020). Tutorial: guidelines for standardized performance tests for electrodes intended for neural interfaces and bioelectronics. Nat. Protocols 15, 3557-3578. doi: 10.1038/ s41596-020-0389-382

Borland, L. M., and Michael, A. C. (2007). "An introduction to electrochemical methods," in Neuroscience. Electrochemical Methods for Neuroscience, eds A. C. Michael and L. M. Borland (Boca Raton, FL: Taylor \& Francis Group, LLC.).

Borland, L. M., Shi, G., Yang, H., and Michael, A. C. (2005). Voltammetric study of extracellular dopamine near microdialysis probes acutely implanted in the striatum of the anesthetized rat. J. Neurosci. Methods 146, 149-158. doi: 10. 1016/j.jneumeth.2005.02.002

Brazell, M. P., Kasser, R. J., Renner, K. J., Feng, J., Moghaddam, B., and Adams, R. N. (1987). Electrocoating carbon fiber microelectrodes with Nafion improves selectivity for electroactive neurotransmitters. J. Neurosci. Methods 22, 167-172. doi: 10.1016/0165-0270(87)90011-90012

Bucher, E. S., and Wightman, R. M. (2015). Electrochemical analysis of neurotransmitters. Ann. Rev. Anal. Chem. 8, 239-261. doi: 10.1146/annurevanchem-071114-40426

Castagnola, E., Robbins, E. M., Woeppel, K. M., McGuier, M., Golabchi, A., Taylor, I. M., et al. (2020). Real-Time fast scan cyclic voltammetry detection and quantification of exogenously administered melatonin in mice brain. Front. Bioeng. Biotechnol. 8:602216. doi: 10.3389/fbioe.2020.602216

Chang, S.-Y., Jay, T., Muñoz, J., Kim, I., and Lee, K. H. (2012). Wireless fast-scan cyclic voltammetry measurement of histamine using WINCS - a proof-ofprinciple study. Analyst 137, 2158-2165. doi: 10.1039/c2an16038b

Chang, A.-Y., Dutta, G., Siddiqui, S., and Arumugam, P. U. (2019). Surface fouling of ultrananocrystalline diamond microelectrodes during dopamine detection: improving lifetime via electrochemical cycling. ACS Chem. Neurosci. 10, 313322. doi: 10.1021/acschemneuro.8b00257

Cheney-Thamm, J., Reite, M., Alianiello, E. A., Yamamoto, B. K., Capitanio, J. P., and Freed, C. R. (1984). Caudate electrochemical response following amphetamine administration in pigtail monkeys. Life Sci. 35, 1453-1460. doi: 10.1016/0024-3205(84)90161-90169

Cheney-Thamm, J., Alianello, E. A., Freed, C. R., and Reite, M. (1987). In vivo electrochemical recording of acetaminophen in non human primate brain. Life Sci. 40, 375-379.

Chong, A., Fischer, G., Dart, B. R., and Wooley, P. H. (2015). Long-term elastic durability of polymer matrix composite materials after repeated steam sterilization. Am. J. Orthoped. 44, E427-E433.

Clark, J. J., Sandberg, S. G., Wanat, M. J., Gan, J. O., Horne, E. A., Hart, A. S., et al. (2010). Chronic microsensors for longitudinal, subsecond dopamine detection in behaving animals. Nat. Methods 7, 126-129. doi: 10.1038/nmeth.1412

Code of Federal Regulations (2021a). Part 812 - Investigational Device Exemptions. Title 21 Chapter I - Subchapter H. e-CFR.

Code of Federal Regulations (2021b). Part 820 - Quality System Regulation. Title 21 - Chapter I - Subchapter H. e-CFR.

Cogan, S. F. (2008). Neural stimulation and recording electrodes. Annu. Rev. Biomed. Eng. 10, 275-309. doi: 10.1146/annurev.bioeng.10.061807.160518

Cogan, S. F., Guzelian, A. A., Agnew, W. F., Yuen, T. G. H., and McCreery, D. B. (2004). Over-pulsing degrades activated iridium oxide films used for intracortical neural stimulation. J. Neurosci. Methods 137, 141-150. doi: 10. 1016/j.jneumeth.2004.02.019

Cogan, S. F., Ludwig, K. A., Welle, C. G., and Takmakov, P. (2016). Tissue damage thresholds during therapeutic electrical stimulation. J. Neural Eng. 13:021001. doi: 10.1088/1741-2560/13/2/021001

DeWaele, M., Oh, Y., Park, C., Kang, Y. M., Shin, H., Blaha, C. D., et al. (2017). A baseline drift detrending technique for fast scan cyclic voltammetry. Analyst 142, 4317-4321. doi: 10.1039/c7an01465a
Earl, C. D., Sautter, J., Xie, J., Kruk, Z. L., Kupsch, A., and Oertel, W. H. (1998). Pharmacological characterisation of dopamine overflow in the striatum of the normal and MPTP-treated common marmoset, studied in vivo using fast cyclic voltammetry, nomifensine and sulpiride. J. Neurosci. Methods 85, 201-209. doi: 10.1016/S0165-0270(98)00134-134

Ganesana, M., Lee, S. T., Wang, Y., and Venton, B. J. (2017). Analytical techniques in neuroscience: recent advances in imaging, separation, and electrochemical methods. Anal. Chem. 89, 314-341. doi: 10.1021/acs.analchem.6b04278

Glover, G. H. (2011). Overview of functional magnetic resonance imaging. Neurosurg. Clin. N. Am. 22, 133-139. doi: 10.1016/j.nec.2010.11.001

Godara, A., Raabe, D., and Green, S. (2007). The influence of sterilization processes on the micromechanical properties of carbon fiber-reinforced PEEK composites for bone implant applications. Acta Biomaterialia 3, 209-220.

Gorna, K., and Gogolewski, S. (2003). The effect of gamma radiation on molecular stability and mechanical properties of biodegradable polyurethanes for medical applications. Polymer Degradation Stabil. 79, 465-474.

Hashemi, P., Walsh, P. L., Guillot, T. S., Gras-Najjar, J., Takmakov, P., Crews, F. T., et al. (2011). Chronically implanted, nafion-coated $\mathrm{Ag} / \mathrm{AgCl}$ reference electrodes for neurochemical applications. ACS Chem. Neurosci. 2, 658-666. doi: $10.1021 / \mathrm{cn} 2000684$

Hermans, A., Keithley, R. B., Kita, J. M., Sombers, L. A., and Wightman, R. M. (2008). Dopamine detection with fast-scan cyclic voltammetry used with analog background subtraction. Anal. Chem. 80, 4040-4048. doi: 10.1021/ac800108j

ISO10993-1:2018 (2018). Biological Evaluation of Medical Devices - Part 1: Evaluation and Testing within a Risk Management Process. Geneva: International Organization for Standardization.

ISO10993-6:2016 (2016). Biological Evaluation of Medical Devices. Part 6: Tests for Local Effects After Implantation. Geneva: International Organization for Standardization.

ISO11737-1:2018 (2018). Sterilization of Health Care Products. Geneva: International Organization for Standardization.

ISO14971:2019 (2019). Medical Devices - Application of Risk Management to Medical Devices. Geneva: International Organization for Standardization.

Jackowska, K., and Krysinski, P. (2013). New trends in the electrochemical sensing of dopamine. Anal. Bioanal. Chem. 405, 3753-3771. doi: 10.1007/s00216-0126578-6572

Jaquins-Gerstl, A., and Michael, A. C. (2015). A review of the effects of FSCV and microdialysis measurements on dopamine release in the surrounding tissue. Analyst 140, 3696-3708. doi: 10.1039/c4an02065k

Johnson, J. A., Gray, J. H., Rodeberg, N. T., and Wightman, R. M. (2017). Multivariate curve resolution for signal isolation from fast-scan cyclic voltammetric data. Anal. Chem. 89, 10547-10555. doi: 10.1021/acs.analchem. $7 \mathrm{~b} 02771$

Johnson, J. A., Rodeberg, N. T., and Wightman, R. M. (2016). Failure of standard training sets in the analysis of fast-scan cyclic voltammetry data. ACS Chem. Neurosci. 7, 349-359. doi: 10.1021/acschemneuro.5b00302

Kachoosangi, R. T., and Compton, R. G. (2007). A simple electroanalytical methodology for the simultaneous determination of dopamine, serotonin and ascorbic acid using an unmodified edge plane pyrolytic graphite electrode. Anal. Bioanal. Chem. 387, 2793-2800. doi: 10.1007/s00216-007-1129-y

Kishida, K. T., Saez, I., Lohrenz, T., Witcher, M. R., Laxton, A. W., Tatter, S. B., et al. (2016). Subsecond dopamine fluctuations in human striatum encode superposed error signals about actual and counterfactual reward. Proc. Natl. Acad. Sci. U S A. 113, 200-205.

Kishida, K. T., Sandberg, S. G., Lohrenz, T., Comair, Y. G., Sáez, I., Phillips, P. E., et al. (2011). Sub-second dopamine detection in human striatum. PLoS One 6:e23291. doi: 10.1371/journal.pone.0023291

Kolli, R., Kaivosoja, E., and Levon, K. (2015). Choice of reference electrode is critical for potentiometric whole cell-based sensor. Electroanalysis 27, 16361641. doi: 10.1002/elan.201400710

Kozai, T. D. Y., Jaquins-Gerstl, A. S., Vazquez, A. L., Michael, A. C., and Cui, X. T. (2015). Brain tissue responses to neural implants impact signal sensitivity and intervention strategies. ACS Chem. Neurosci. 6, 48-67. doi: 10.1021/cn500256e

Lee, K. H., Chang, S. Y., Jang, D. P., Kim, I., Goerss, S., Van Gompel, J., et al. (2011). Emerging techniques for elucidating mechanism of action of deep brain stimulation. Conf. Proc. IEEE Eng. Med. Biol. Soc. 2011, 677-680. doi: 10.1109/IEMBS.2011.6090152

Lee, K. H., Lujan, J. L., Trevathan, J. K., Ross, E. K., Bartoletta, J. J., Park, H. O., et al. (2017). WINCS harmoni: closed-loop dynamic neurochemical 
control of therapeutic interventions. Sci. Rep. 7:46675. doi: 10.1038/srep 46675

Lind, N. M., Moustgaard, A., Jelsing, J., Vajta, G., Cumming, P., and Hansen, A. K. (2007). The use of pigs in neuroscience: modeling brain disorders. Neurosci. Biobehav. Rev. 31, 728-751. doi: 10.1016/j.neubiorev.2007.02.003

Lohrenz, T., Kishida, K. T., and Montague, P. R. (2016). BOLD and its connection to dopamine release in human striatum: a cross-cohort comparison. Philos. Trans. R. Soc. B: Biol. Sci. 371:20150352.

Lucas, A. D., Merritt, K., Hitchins, V. M., Woods, T. O., McNamee, S. G., Lyle, D. B., et al. (2003). Residual ethylene oxide in medical devices and device material. J. Biomed. Mater. Res. Part B: Appl. Biomater. 66, 548-552.

Martin, H. B., Smith, B. A., Angus, J. C., Landau, U., and Anderson, A. B. (1998). Boron-Doped diamond films for electrochemical applications. MRS Proc. 555:217. doi: 10.1557/PROC-555-217

McCreery, D. B., Agnew, W. F., Yuen, T. G., and Bullara, L. (1990). Charge density and charge per phase as cofactors in neural injury induced by electrical stimulation. IEEE Trans. Biomed. Eng. 37, 996-1001. doi: 10.1109/10.102812

McCreery, D. B., Agnew, W. F., Yuen, T. G., and Bullara, L. A. (1988). Comparison of neural damage induced by electrical stimulation with faradaic and capacitor electrodes. Ann. Biomed. Eng. 16, 463-481. doi: 10.1007/bf02368010

McDermott, M. T., and McCreery, R. L. (1994). Scanning tunneling microscopy of ordered graphite and glassy carbon surfaces: electronic control of quinone adsorption. Langmuir 10, 4307-4314.

Mendes, G. C., Brandao, T. R., and Silva, C. L. (2007). Ethylene oxide sterilization of medical devices: a review. Am. J. Infect. Control 35, 574-581.

Meunier, C. J., Mitchell, E. C., Roberts, J. G., Toups, J. V., McCarty, G. S., and Sombers, L. A. (2018). Electrochemical selectivity achieved using a double voltammetric waveform and partial least squares regression: differentiating endogenous hydrogen peroxide fluctuations from shifts in pH. Anal. Chem. 90, 1767-1776. doi: 10.1021/acs.analchem.7b03717

Millar, J., Stamford, J. A., Kruk, Z. L., and Wightman, R. M. (1985). Electrochemical, pharmacological and electrophysiological evidence of rapid dopamine release and removal in the rat caudate nucleus following electrical stimulation of the median forebrain bundle. Eur. J. Pharmacol. 109, 341-348. doi: 10.1016/0014-2999(85)90394-90392

Min, H. K., Ross, E. K., Jo, H. J., Cho, S., Settell, M. L., Jeong, J. H., et al. (2016). Dopamine release in the nonhuman primate caudate and putamen depends upon site of stimulation in the subthalamic nucleus. J. Neurosci. 36, 6022-6029. doi: 10.1523/JNEUROSCI.0403-16.2016

Mitchell, E. C., Dunaway, L. E., McCarty, G. S., and Sombers, L. A. (2017). Spectroelectrochemical characterization of the dynamic carbon-fiber surface in response to electrochemical conditioning. Langmuir 33, 7838-7846.

Mohanaraj, S., Wonnenberg, P., Cohen, B., Zhao, H., Hartings, M. R., Zou, S., et al. (2019). Gold nanoparticle modified carbon fiber microelectrodes for enhanced neurochemical detection. J. Vis. Exp.

Montague, P. R., and Kishida, K. T. (2018). Computational underpinnings of neuromodulation in humans. Cold. Spring Harb. Symp. Quant. Biol. 83, 71-82. doi: $10.1101 /$ sqb.2018.83.038166

Moquin, K. F., and Michael, A. C. (2009). Tonic autoinhibition contributes to the heterogeneity of evoked dopamine release in the rat striatum. J. Neurochem. 110, 1491-1501. doi: 10.1111/j.1471-4159.2009.06254.x

Moran, R. J., Kishida, K. T., Lohrenz, T., Saez, I., Laxton, A. W., Witcher, M. R., et al. (2018). The protective action encoding of serotonin transients in the human brain. Neuropsychopharmacology 43, 1425-1435. doi: 10.1038/npp.2017.304

Nair, P. D. (1995). Currently practised sterilization methods-some inadvertent consequences. J. Biomater. Appl. 10, 121-135.

Nakajima, A., Shimo, Y., Uka, T., and Hattori, N. (2017). Subthalamic nucleus and globus pallidus interna influence firing of tonically active neurons in the primate striatum through different mechanisms. Eur. J. Neurosci. 46, 26622673.

Nicolai, E. N., Trevathan, J. K., Ross, E. K., Lujan, J. L., Blaha, C. D., Bennet, K. E., et al. (2017). Detection of norepinephrine in whole blood via fast scan cyclic voltammetry. IEEE Int. Symp. Med. Meas. Appl. 2017, 111-116. doi: 10.1109/MeMeA.2017.7985859

Olivieri, A. C. (2008). Analytical advantages of multivariate data processing. one, two, three, infinity? Anal. Chem. 80, 5713-5720. doi: 10.1021/ac800692c

Park, J. H., Chung, S. J., Lee, C. S., and Jeon, S. R. (2011). Analysis of hemorrhagic risk factors during deep brain stimulation surgery for movement disorders: comparison of the circumferential paired and multiple electrode insertion methods. Acta Neurochir (Wien) 153, 1573-1578. doi: 10.1007/s00701-0110997-992

Patel, A. N., Tan, S.-Y., Miller, T. S., Macpherson, J. V., and Unwin, P. R. (2013). Comparison and reappraisal of carbon electrodes for the voltammetric detection of dopamine. Anal. Chem. 85, 11755-11764.

Patel, P. R., Zhang, H., Robbins, M. T., Nofar, J. B., Marshall, S. P., Kobylarek, M. J., et al. (2016). Chronic in vivo stability assessment of carbon fiber microelectrode arrays. J. Neural Eng. 13:066002. doi: 10.1088/1741-2560/13/6/066002

Phillips, K. A., Bales, K. L., Capitanio, J. P., Conley, A., Czoty, P. W., 't Hart, B. A., et al. (2014). Why primate models matter. Am. J. Primatol. 76, 801-827. doi: 10.1002/ajp.22281

Pihel, K., Walker, Q. D., and Wightman, R. M. (1996). Overoxidized polypyrrolecoated carbon fiber microelectrodes for dopamine measurements with fast-scan cyclic voltammetry. Anal. Chem. 68, 2084-2089. doi: 10.1021/ac960153y

Puthongkham, P., and Venton, B. J. (2019). Nanodiamond coating improves the sensitivity and antifouling properties of carbon fiber microelectrodes. ACS Sensors 4, 2403-2411.

Rajendrachari, S. (2018). Investigation of Electrochemical Pitting Corrosion by Linear Sweep Voltammetry: A Fast and Robust Approach. Voltammetry. London: IntechOpen.

Ramsson, E. S., Cholger, D., Dionise, A., Poirier, N., Andrus, A., and Curtiss, R. (2015). Characterization of fast-scan cyclic voltammetric electrodes using paraffin as an effective sealant with in vitro and in vivo applications. PLoS One 10:e0141340. doi: 10.1371/journal.pone.0141340

Ries, M. D., Weaver, K., Rose, R. M., Gunther, J., Sauer, W., and Seals, N. (1996). Fatigue strength of polyethylene after sterilization by gamma irradiation or ethylene oxide. Clin. Orthopaed. Related Res. 333, 87-95.

Robblee, L. S., and Rose, T. L. (1990). "The electrochemistry of electrical stimulation," in Proceedings of the 20th Annual International Conference of the IEEE Engineering in Medicine and Biology Society, (Piscataway, NJ: IEEE), 1479-1480.

Roberts, J. G., and Sombers, L. A. (2018). Fast-Scan cyclic voltammetry: chemical sensing in the brain and beyond. Anal. Chem. 90, 490-504. doi: 10.1021/acs. analchem.7b04732

Rodeberg, N. T., Sandberg, S. G., Johnson, J. A., Phillips, P. E. M., and Wightman, R. M. (2017). Hitchhiker's guide to voltammetry: acute and chronic electrodes for in vivo fast-scan cyclic voltammetry. ACS Chem. Neurosci. 8, 221-234. doi: 10.1021/acschemneuro.6b00393

Ross, E. K., Kim, J. P., Settell, M. L., Han, S. R., Blaha, C. D., Min, H.-K., et al. (2016). Fornix deep brain stimulation circuit effect is dependent on major excitatory transmission via the nucleus accumbens. Neuroimage 128, 138-148. doi: 10.1016/j.neuroimage.2015.12.056

Sansur, C. A., Frysinger, R. C., Pouratian, N., Fu, K. M., Bittl, M., Oskouian, R. J., et al. (2007). Incidence of symptomatic hemorrhage after stereotactic electrode placement. J. Neurosurg. 107, 998-1003. doi: 10.3171/jns-07/11/0998

Schluter, E. W., Mitz, A. R., Cheer, J. F., and Averbeck, B. B. (2014). Real-time dopamine measurement in awake monkeys. PLoS One 9:e98692. doi: 10.1371/ journal.pone.0098692

Schwerdt, H. N., Shimazu, H., Amemori, K.-I., Amemori, S., Tierney, P. L., Gibson, D. J., et al. (2017b). Long-term dopamine neurochemical monitoring in primates. Proc. Natl. Acad. Sci. U S A. 114, 13260-13265. doi: 10.1073/pnas. 1713756114

Schwerdt, H. N., Kim, M. J., Amemori, S., Homma, D., Yoshida, T., Shimazu, H., et al. (2017a). Subcellular probes for neurochemical recording from multiple brain sites. Lab. Chip 17, 1104-1115. doi: 10.1039/c6lc01398h

Seaton, B. T., Hill, D. F., Cowen, S. L., and Heien, M. L. (2020). Mitigating the effects of electrode biofouling-induced impedance for improved long-term electrochemical measurements in vivo. Anal. Chem. 92, 6334-6340. doi: 10. 1021/acs.analchem.9b05194

Settell, M. L., Testini, P., Cho, S., Lee, J. H., Blaha, C. D., Jo, H. J., et al. (2017). Functional circuitry effect of ventral tegmental area deep brain stimulation: imaging and neurochemical evidence of mesocortical and mesolimbic pathway modulation. Front. Neurosci. 11:104. doi: 10.3389/fnins.2017.00104

Shannon, R. V. (1992). A model of safe levels for electrical stimulation. IEEE Trans. Biomed. Eng. 39, 424-426. doi: 10.1109/10.126616

Shon, Y. M., Lee, K. H., Goerss, S. J., Kim, I. Y., Kimble, C., Van Gompel, J. J., et al. (2010). High frequency stimulation of the subthalamic nucleus evokes 
striatal dopamine release in a large animal model of human DBS neurosurgery. Neurosci. Lett. 475, 136-140. doi: 10.1016/j.neulet.2010.03.060

Stamford, J. A., Kruk, Z. L., Millar, J., and Wightman, R. M. (1984). Striatal dopamine uptake in the rat: in vivo analysis by fast cyclic voltammetry. Neurosci. Lett. 51, 133-138. doi: 10.1016/0304-3940(84)90274-x

Suaud-Chagny, M. F., Chergui, K., Chouvet, G., and Gonon, F. (1992). Relationship between dopamine release in the rat nucleus accumbens and the discharge activity of dopaminergic neurons during local in vivo application of amino acids in the ventral tegmental area. Neuroscience 49, 63-72. doi: 10.1016/03064522(92)90076-E

Suzuki, A., Ivandini, T. A., Yoshimi, K., Fujishima, A., Oyama, G., Nakazato, T., et al. (2007). Fabrication, characterization, and application of boron-doped diamond microelectrodes for in vivo dopamine detection. Anal. Chem. 79, 8608-8615. doi: 10.1021/ac071519h

Taylor, I. M., Nesbitt, K. M., Walters, S. H., Varner, E. L., Shu, Z., Bartlow, K. M., et al. (2015). Kinetic diversity of dopamine transmission in the dorsal striatum. J. Neurochem. 133, 522-531. doi: 10.1111/jnc.13059

Trevathan, J. K., Yousefi, A., Park, H. O., Bartoletta, J. J., Ludwig, K. A., Lee, K. H., et al. (2017). Computational modeling of neurotransmitter release evoked by electrical stimulation: nonlinear approaches to predicting stimulation-evoked dopamine release. ACS Chem. Neurosci. 8, 394-410.

Van Gompel, J. J., Bower, M. R., Worrell, G. A., Stead, M., Chang, S.-Y., Goerss, S. J., et al. (2014). Increased cortical extracellular adenosine correlates with seizure termination. Epilepsia 55, 233-244. doi: 10.1111/epi.12511

Vreeland, R. F., Atcherley, C. W., Russell, W. S., Xie, J. Y., Lu, D., Laude, N. D., et al. (2015). Biocompatible PEDOT:Nafion composite electrode coatings for selective detection of neurotransmitters in vivo. Anal. Chem. 87, 2600-2607. doi: 10.1021/ac502165f

Wang, Y., and Michael, A. C. (2012). Microdialysis probes alter presynaptic regulation of dopamine terminals in rat striatum. J. Neurosci. Methods 208, 34-39. doi: 10.1016/j.jneumeth.2012.04.009

Wightman, R. M., Heien, M. L., Wassum, K. M., Sombers, L. A., Aragona, B. J., Khan, A. S., et al. (2007). Dopamine release is heterogeneous within microenvironments of the rat nucleus accumbens. Eur. J. Neurosci. 26, 20462054. doi: 10.1111/j.1460-9568.2007.05772.x

Woolley, A. J., Desai, H. A., and Otto, K. J. (2013). Chronic intracortical microelectrode arrays induce non-uniform, depth-related tissue responses. J. Neural Eng. 10:026007. doi: 10.1088/1741-2560/10/2/026007

Yang, C., Trikantzopoulos, E., Jacobs, C. B., and Venton, B. J. (2017). Evaluation of carbon nanotube fiber microelectrodes for neurotransmitter detection: correlation of electrochemical performance and surface properties. Anal. Chim. Acta 965, 1-8. doi: 10.1016/j.aca.2017.01.039

Yoshimi, K., Kumada, S., Weitemier, A., Jo, T., and Inoue, M. (2015). RewardInduced phasic dopamine release in the monkey ventral striatum and putamen. PLoS One 10:e0130443. doi: 10.1371/journal.pone.0130443

Yoshimi, K., Naya, Y., Mitani, N., Kato, T., Inoue, M., Natori, S., et al. (2011). Phasic reward responses in the monkey striatum as detected by voltammetry with diamond microelectrodes. Neurosci. Res. 71, 49-62.

Zachek, M. K., Hermans, A., Wightman, R. M., and McCarty, G. S. (2008). Electrochemical dopamine detection: comparing gold and carbon fiber microelectrodes using background subtracted fast scan cyclic voltammetry. J. Electroanal Chem. (Lausanne) 614, 113-120. doi: 10.1016/j.jelechem.2007.11.007

Zachek, M. K., Park, J., Takmakov, P., Wightman, R. M., and McCarty, G. S. (2010). Microfabricated FSCV-compatible microelectrode array for real-time monitoring of heterogeneous dopamine release. Analyst 135, 1556-1563. doi: 10.1039/c0an00114g

Zachek, M. K., Takmakov, P., Moody, B., Wightman, R. M., and McCarty, G. S. (2009). Simultaneous decoupled detection of dopamine and oxygen using pyrolyzed carbon microarrays and fast-scan cyclic voltammetry. Anal. Chem. 81, 6258-6265. doi: 10.1021/ac900790m

Zhao, Y., Li, S.-H., Chu, J., Chen, Y.-P., Li, W.-W., Yu, H.-Q., et al. (2012). A nanosized Au electrode fabricated using lithographic technology for electrochemical detection of dopamine. Biosens. Bioelectron. 35, 115-122. doi: 10.1016/j.bios. 2012.02.030

Zheng, J., Clogston, J. D., Patri, A. K., Dobrovolskaia, M. A., and McNeil, S. E. (2011). Sterilization of silver nanoparticles using standard gamma irradiation procedure affects particle integrity and biocompatibility. J. Nanomed. Nanotechnol. 2011(Suppl. 5):001.

Conflict of Interest: We declare that the following investigators Kenneth $\mathrm{T}$. Kishida, P. Read Montague, Charles D. Blaha, Michael Heien, Kendall H. Lee, Terry Lohrenz may present conflict of interest with the ideas presented in this review because of their past or current use of fast scan cyclic voltammetry in humans.

The authors declare that the research was conducted in the absence of any commercial or financial relationships that could be construed as a potential conflict of interest.

Publisher's Note: All claims expressed in this article are solely those of the authors and do not necessarily represent those of their affiliated organizations, or those of the publisher, the editors and the reviewers. Any product that may be evaluated in this article, or claim that may be made by its manufacturer, is not guaranteed or endorsed by the publisher.

Copyright (C) 2021 Lucio Boschen, Trevathan, Hara, Asp and Lujan. This is an openaccess article distributed under the terms of the Creative Commons Attribution License (CC BY). The use, distribution or reproduction in other forums is permitted, provided the original author(s) and the copyright owner(s) are credited and that the original publication in this journal is cited, in accordance with accepted academic practice. No use, distribution or reproduction is permitted which does not comply with these terms. 